University of Louisville

ThinkIR: The University of Louisville's Institutional Repository

$5-2012$

\title{
Administrator and band director perceptions of the implementation of KY Core Content for Assessment in Music.
}

David A. Buchholz 1985-

University of Louisville

Follow this and additional works at: https://ir.library.louisville.edu/etd

\section{Recommended Citation}

Buchholz, David A. 1985-, "Administrator and band director perceptions of the implementation of KY Core Content for Assessment in Music." (2012). Electronic Theses and Dissertations. Paper 173.

https://doi.org/10.18297/etd/173

This Master's Thesis is brought to you for free and open access by ThinkIR: The University of Louisville's Institutional Repository. It has been accepted for inclusion in Electronic Theses and Dissertations by an authorized administrator of ThinkIR: The University of Louisville's Institutional Repository. This title appears here courtesy of the author, who has retained all other copyrights. For more information, please contact thinkir@louisville.edu. 


\title{
ADMINISTRATOR AND BAND DIRECTOR PERCEPTIONS OF THE IMPLEMENTATION OF KY CORE CONTENT FOR ASSESSMENT IN MUSIC
}

\author{
By \\ David A. Buchholz \\ B.M.E., University of Louisville, 2008 \\ A Thesis Submitted to the Faculty of the \\ School of Music of the University of Louisville \\ in Partial Fulfillment of the Requirements \\ for the Degree of
}

Master of Music Education

School of Music

University of Louisville

Louisville, $\mathrm{KY}$

May 2012 


\section{ADMINISTRATOR AND BAND DIRECTOR PERCEPTIONS \\ OF THE IMPLEMENTATION OF KY CORE CONTENT FOR ASSESSMENT IN MUSIC}

\section{By}

David A. Buchholz

B.M.E., University of Louisville, 2008

\section{A Thesis Approved on}

April 25, 2012

By the following Thesis Committee:

Robert A. Amchin, Thesis Director

Amy Acklin

Darcy D. Walworth 


\section{DEDICATION}

This work is dedicated, with love and admiration, to my family.

To my parents, David and Ginny Buchholz; you have always encouraged my musical endeavors and your love and exceedingly high academic expectations have never allowed me get by without putting forth my best effort.

To my brothers, Henry and Steve; you always push me to do my best-even if only to say, that I did it "better" than you did. Isn't that what brothers are for?

To my Aunt Kathy; you have been to every concert, award ceremony, and too many soccer and baseball games to recount, to cheer me on and provide your support.

To my Aunt Barb, "ABC"; you may not have lived nearby, but you have been as close in spirit as anyone in your support and encouragement of my schooling and music.

And finally, to my adoring wife, Amanda; your support has been irreplaceable throughout the past two years. I am a better student, teacher, and, most importantly, a better person because of you. 


\section{ACKNOWLEDGEMENTS}

I would like to thank Dr. Robert Amchin, my thesis advisor, for his guidance and support over the course of this project, my graduate study, and my undergraduate study. I would like to thank Dr. Amy Acklin for teaching me the ropes of academic research and making what could otherwise have been a dull topic, interesting and enjoyable. I would also like to thank the final member of my committee, Dr. Darcy Walworth, for taking time out of her very busy schedule to read and provide helpful criticism about my research. I would like to thank my friend and colleague, Ms. Ashley Mattingly for all of her help and motivation as we tackled our thesis projects together this year. Finally, I would like to acknowledge all of my family and friends that have helped and supported me for the past $26 \frac{1 / 2}{2}$ years. 


\begin{abstract}
ADMINISTRATOR AND BAND DIRECTOR PERCEPTIONS

OF THE IMPLEMENTATION OF KY CORE CONTENT

FOR ASSESSMENT IN MUSIC
\end{abstract}

David A. Buchholz

April 25, 2012

The purpose of this study was to survey secondary school administrator and band director perceptions regarding the implementation of Kentucky's Core Content for Assessment 4.1 (CCA 4.1) in Music in the band programs at their schools. Secondary topics addressed included how administrators observe and assess their program with regards to KY CCA 4.1 and how band directors implement the different content standards set forth in KY CCA 4.1. An online survey using both Likert-type questions and short answer open response questions was completed by secondary public school administrators $(n=20)$ and band directors $(n=17)$ in a major metropolitan region in the Southeast. Results indicate that band directors were generally more critical of their instruction with respect to the content standards than administrators. Additionally, gaps were found in the assessment of standards relating to creating and composing music and improvising, between what administrators are observing and band directors are implementing. Suggestions for future research are offered. 


\section{TABLE OF CONTENTS}

PAGE

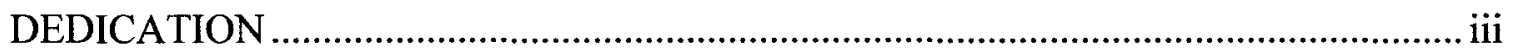

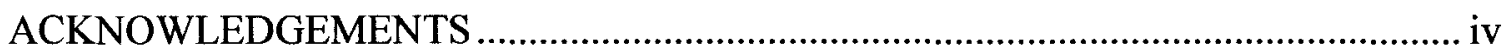

ABSTRACT .

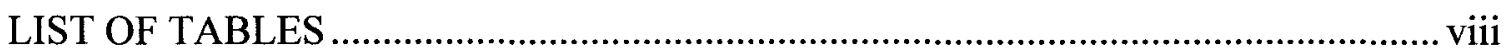

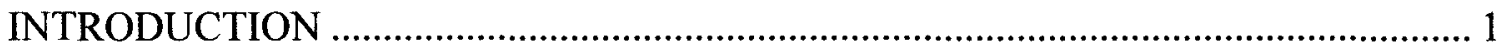

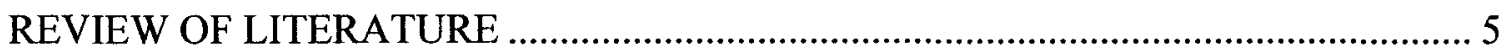

Introduction to the Review of Literature............................................................... 5

The Extra-Musical Benefits of Music Instruction............................................. 6

A Philosophical Basis for Music Instruction ........................................................ 9

Subjective Ways of Evaluating Music Programs................................................. 14

The National Standards in Music Education.................................................... 17

Kentucky's Core Content for Assessment .......................................................... 23

Teacher Perceptions of the National Standards ................................................... 26

The State of Music Instruction in the Schools ..................................................... 30

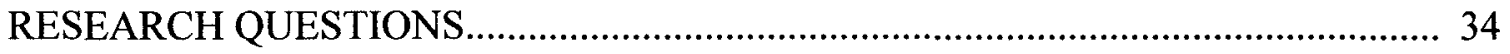

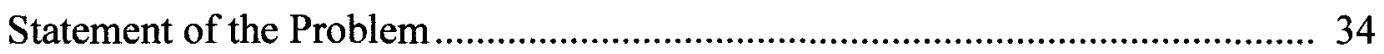

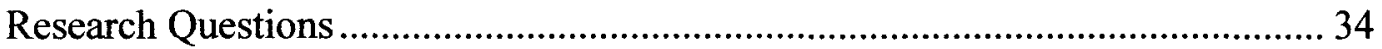

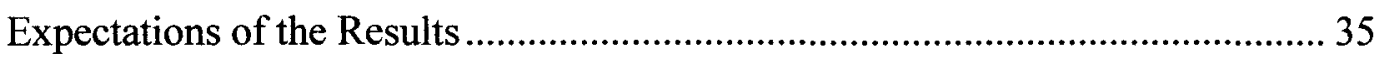

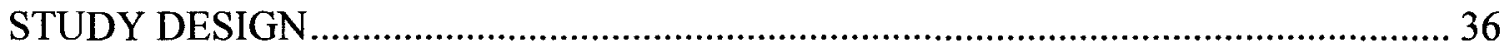

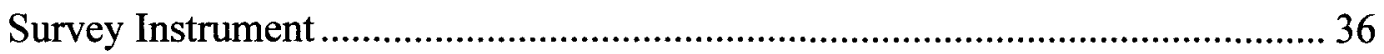




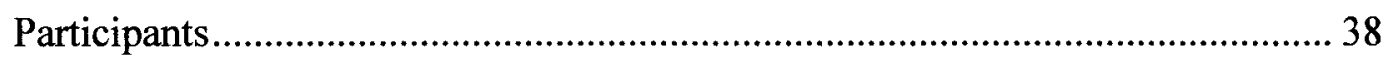

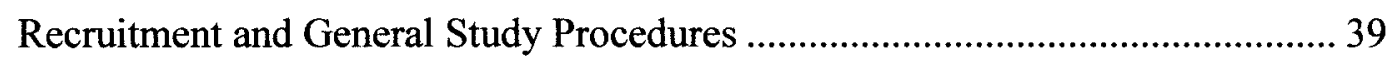

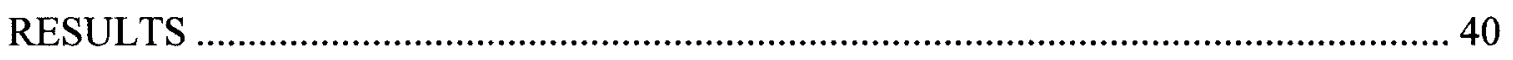

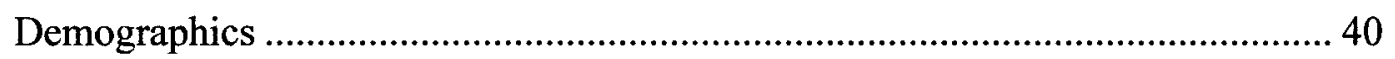

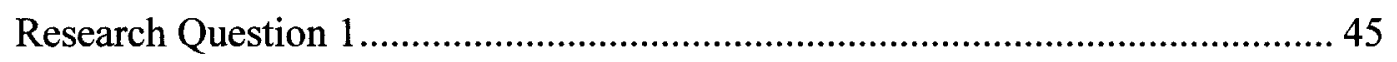

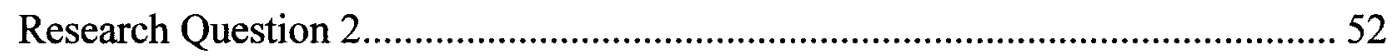

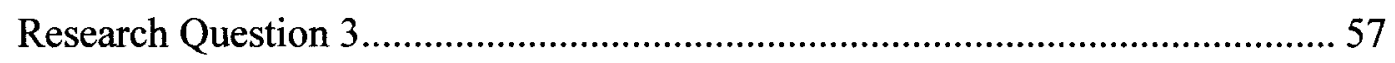

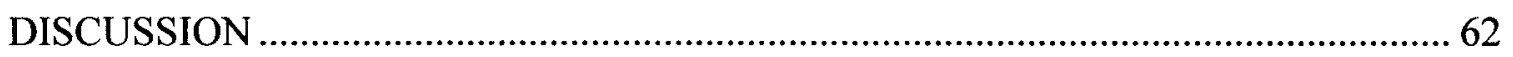

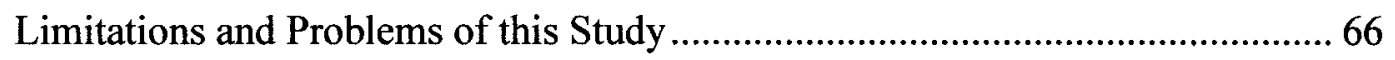

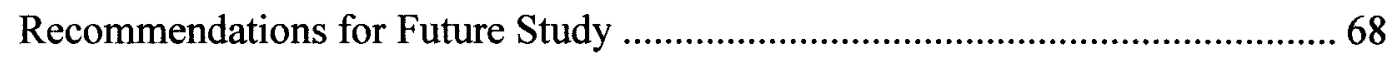

REFERENCES

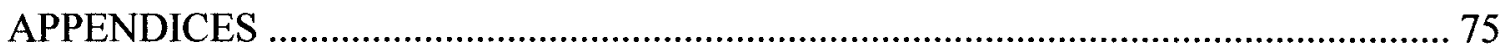

Appendix A: Kentucky Core Content for Assessment 4.1 in Music ................... 75

Appendix B: Recruiting Letters (Administrators) .............................................. 77

Appendix C: Recruiting Letters (Band Director) .................................................. 79

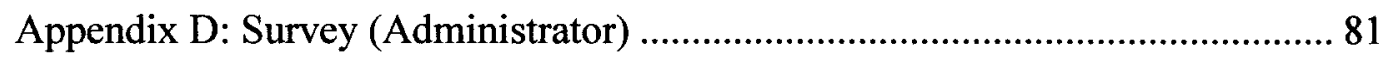

Appendix E: Survey (Band Director)............................................................... 94

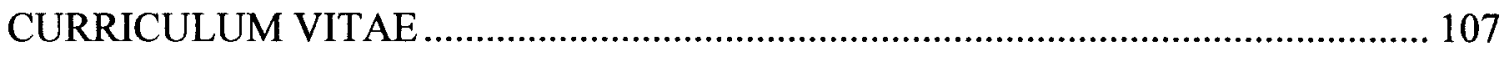




\section{LIST OF TABLES}

TABLE

PAGE

1. "What grade levels does you school serve?" ............................................................... 41

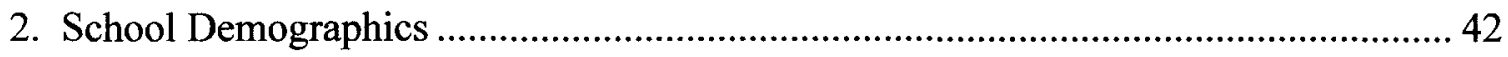

3. Average Number of Music Specialists Teaching in Each School and the Number of Music Specialists Teaching Band .................................................. 43

4. Other Courses Taught by Band Directors ...................................................................... 44

5. Proportion of School Population Enrolled in Band as Reported by Band Directors ........................................................................ 45

6. Content Themes for Analysis of Aggregate Administrator and Band Director Data.

7. Administrator and Band Director Ratings of the Implementation of KY CCA 4.1

8. Composite Likert-Scale Ratings Given by Administrators and Band Directors on All 19 Items.

9. How Administrators Reported Observing Standard Implementation in the Band Program.

10. Activities Observed by Administrators During the Implementation of Standards in the Band Program

11. Administrator Responses that Listed a Single Course or Courses Where a Standard has Been Implemented.

12. How Band Directors Reported Implementing the Standards in the Band Program 


\section{INTRODUCTION}

In an era of greater accountability for American public schools, music educators have sometimes struggled to justify music's place in the curriculum. In an effort to provide this needed justification, some music educators have sought to define the benefits of music instruction in extra-musical terms. For instance, listening to Mozart has been purported to increase some spatial reasoning scores in children-the Governor of Georgia was so enthralled with this theory that he used state tax dollars to purchase CDs for all newborn babies in Georgia.

This may appear to be a breakthrough for educators seeking to justify music in the schools however, Bennett Reimer, a prominent philosopher in music education, warns of the impact that basing music instruction solely on this information could have on the music curriculum and the role of music in the schools. Using a wry tone, Mr. Reimer (1999) unmercifully dismantles music education as we know it, based on the results of existing research regarding music's effect on extra-musical cognitive ability. Indeed, his writing may border on hyperbole, but in this era of endless assessment that is often guided by the "latest" research in topics such as "improving reading comprehension," it is not difficult to envision music education being justified and guided on such an outlandish basis.

Others, it would seem, are set on justifying music for its purely intrinsic qualities. While music does have very important qualities of its own that need to be emphasized, 
and Howard Gardner has suggested that music is one of many distinct ways in which humans beings can think, the nature of our economy and consequently our culture requires that music be justified on more easily assessable terms if it is to be viable. Indeed, many will take stances similar to those of Eisner in which he describes the unique benefits of arts instruction (1958) and dismisses the traditional use of educational objectives and assessments (1967) in arts education. But as education becomes more and more governed by the legislative bodies that control American tax dollars, a means of proving the acquisition of musical knowledge and ability is becoming more and more of a goal for music educators. Unfair as it may seem, research on music's extra-musical benefits for learning and the use of standardized assessments to judge music learning will have a seat at the bargaining table- - it is up to our profession to determine the extent to which outside factors control the music learning process.

For a long time, music educators were unable to come to an agreement as to what they were seeking to do in the classroom-teaching for performances, for knowledge of theory or history, the identification of great works of art music, the teaching of pop genres or, culturally relevant music. The work of philosophers and other leaders of thought in the profession subsequently came to an agreement upon what should be taught in music classes, whether general music, choir, band, or theory: the National Standards for music education-nine standards that seek to balance music making with understanding.

From these standards-skills all students should be able to demonstrate upon completion of schooling - music educators can begin to evaluate the use of, and consequent benefits of assessment and standardized testing in music. Fisher (2008), does 
a good job of capturing both sides of the argument surrounding assessment in music, but ultimately concurs with the pro-assessment faction on the basis of the benefits assessment in music can provide: accountability, political gain, protection of instruction time, and as gauge for music programs across the country. No matter what side of the argument is taken, it appears as if the use of standards and standards-based assessment is not going to evaporate any time soon. At any rate, the standards provide a framework from which to provide for the whole music education of the students, not simply performing and not merely learning facts and passively listening.

While the National Standards for music education have allowed for the cohesion of music instruction and assessment nationwide, states have also adopted or developed their own standards for music instruction. Kentucky is no exception to this trend. With the passage of the Kentucky Education Reform Act (KERA) of 1990, Kentucky adopted a set of six broad learner goals that were to be framed within each curricular subject, including music, with the standards for assessment that subsequently became Kentucky's Core Content for Assessment. Initially these standards were assessed using paper-andpencil tests, including music, but after the passage of Senate Bill 1 in 2009, a program review process was adopted to allow for authentic assessment in the arts. Nevertheless, Kentucky's Core Content standards drive the planning, instruction, and assessment in every curricular area as teachers and administrators work to claim their piece of the pie through high achievement on statewide, high-stakes standardized tests.

Among the many stakeholders in public education, administrators, like managers and corporate executives, are responsible for the programs and instruction within their buildings. When provided with the proper information (read: data), they can become 
advocates for music instruction — providing the time, space, and funds needed to run a high-quality music program. At the secondary school level, principals are often only exposed to their music programs through performances and the occasional observation or walk-through of an ensemble rehearsal. They may or may not witness all of the learning that takes place or even know necessarily when a standard has been covered, due to the unique nature of rehearsals. Given the importance of administrators as both "the boss"responsible for assessing each teacher's quality of work — and as an advocate - lobbying for resources on behalf of the music educator-it stands to reason, that music educators should actively seek out the perceptions of their administrators regarding the content being taught in secondary school music programs. Abril and Gault $(2006,2008)$ have undertaken this premise and the current study will partially replicate their work. 


\section{CHAPTER 1}

\section{REVIEW OF LITERATURE}

\section{INTRODUCTION TO THE REVIEW OF LITERATURE}

Over the last several decades, music education has found itself in a rather precarious position; caught between the aesthetic goals that are true to the nature of music and the cultural, political, and economic pressures of accountability and high-stakes standardized testing. To teach to the aesthetic basis for music education risks alienating administrators and politicians who want proof, usually in the form of numerically quantifiable data and statistics. On the other hand, to try and develop objective systems of assessment in the arts can very quickly reduce music to a series of multiple choice questions that assess only the historically factual or elementarily definable aspects of music. This is hardly a musical outcome.

In this day of limited funding and greater accountability a middle ground has been sought; "how do we continue to justify music as an aesthetic component of every child's education and at the same time, ensure that we are accountable for teaching about music beyond the next performance and simple, often arbitrary, ratings of 'superior,' 'proficient,' 'I,' etc.?" For some, defending music education relies upon participation in musical instruction as secondary to music itself — as enhancing cognitive performance and results in other academic disciplines, that is music for math's sake. Others, including 
large organizations and bodies of music professionals have set about developing a standards-based approach to music instruction that parallels what has been done in the other curricular subjects most subjected to high-stakes standardized testing. This chapter will subsequently explore research investigating music instruction's impact on extramusical activities and standardized test scores, a more philosophical basis for music education, and the standards-based approach to music instruction.

\section{THE EXTRA-MUSICAL BENEFITS OF MUSIC INSTRUCTION}

Music instruction is often informally assessed through music's many perceived extra-musical benefits or outcomes. The Mozart effect is perhaps the most famous example of music's affect on other areas of cognitive performance. Specifically, the Mozart effect refers to the results of a study by Rauscher, Shaw, and Ky (1995; this was a replication of a study by Rauscher et al., published in 1993). Listening to a very specific Mozart piano sonata, K. 488, produced gains in a spatial-temporal reasoning task when compared with sitting in silence, or in the 1995 replication, Music with Changing Parts by Philip Glass. This theory has been highly scrutinized due to an inability to replicate the results or results that are attributed to other variables. Steele, Bass, and Crook (1995) and Schellenburg (2005) have attributed the effects of listening to Mozart to other factors, such as mood and arousal that are affected by listening to any piece of music or even reading a book. Schellenburg cites evidence to support a "Schubert effect," a "Stephen King effect," and even a "children's play song effect," however, no "Albinoni effect" was found. Steele, Bass and Crook in a replication of Rauscher, et al. (1995) found that the 
mood stimulated in the listening of music may have an effect on the results.

Furthermore, Črnčec, Wilson, and Prior (2006) found that there is no evidence for the Mozart effect in young children. Despite the evidence against the Mozart effect and music educators' 'outrage," Rauscher (1999) supports the use of music's extra-musical benefits to justify music instruction as important to "optimal development" of children."

Another common set of information disseminated to the public in support of longterm participation in the arts is drawn from SAT and ACT scores. But perhaps the scores of students on these tests "potentially tell us more about our students than about the effects of music" (Demorest \& Morrison, 2000, pg. 37). Instead of interpreting this data as something that is characteristic of students actively engaged in music, proponents of this information interpret it as music impacting the students. Demorest and Morrison go on to say that while music scores are above average on the math and verbal components of the SAT, especially when compared to students not involved in the arts, they are still not the highest, as students in acting and drama appreciation score even higher in these areas. Furthermore, students involved in classical and foreign language study show greater increases in SAT scores over time than similar students enrolled in fine arts. The authors attribute part of these increases to attrition in fine arts and music programs. It is cautioned that one should be careful when evaluating this information in an artificial vacuum of music education.

\footnotetext{
1 "Although many music educators and others are outraged (and rightly so) that the justification for music may lie in research revealing its extra-musical benefits, I believe that to exclude these studies from discussions arguing for music in the schools is to 'cut off one's nose to spite one's face." (Rauscher, 1999, pg. 44)

2 "I suggest that music education is important for optimal development, and that we use all available information to ensure a quality education for our children." (Rauscher, 1999, pg. 45)
} 
The inability of research to establish that music can, without a doubt, enhance the cognitive abilities of students in arenas beyond music lends credence to the existence of a musical intelligence, as posited by Howard Gardner and the need for music instruction for music's sake alone. However, some researchers have examined the effect of instrumental music instruction on specific academic content tests and their related cognitive skills. For instance, Zellner (2011) found a positive relationship between instrumental music instruction and critical thinking skills as assessed by the math and reading content areas of the Pennsylvania System of School Assessment.

Fitzpatrick (2006) evaluated the test scores of Columbus, Ohio students on all areas of the Ohio Proficiency Test. Instrumental students of both socioeconomic statuses outperformed their non-instrumental peers with instrumental students receiving free and reduced price lunches outperforming the non-instrumental students at the higher economic status on four of five content areas, an interesting trend worthy of note. Another study from Columbus, Ohio examined the effect of the Arts IMPACT ${ }^{3}$ curriculum on the Fourth-Grade Ohio Proficiency Test scores. Data suggest a positive impact on the math, citizenship, and science scores of students in the schools employing the IMPACT curriculum and an even greater effect on students from a lower socioeconomic background. The authors conclude that the Arts IMPACT curriculum exists, in part, to support other subjects and "apparently the programs [are] succeed[ing] in doing so."

\footnotetext{
${ }^{3}$ The Arts IMPACT (Interdisciplinary Model Program in the Arts for Children and Teachers) program began in the 1970s at select elementary schools in the Columbus schools and has as its purpose the goal of "infuse[ing] and integrat[ing the] arts into the curriculum." The program, which has received mixed support from district administration over the years, employs full-time music, art, dance, and drama teachers and features frequent and regular instruction (Kinney \& Forsythe, 2005, pg. 38).
} 
The quality of music instruction and its effect on standardized test scores was examined by Johnson and Memmott (2006). They found that generally higher quality music programs were accompanied by higher standardized tests scores however, they suggest that there is no evidence that participating in a good music program will necessarily increase student test scores. Finally, Gordon (1979) found that daily reading achievement increased with contingent music instruction and was not maintained when the contingency was removed, adding yet another behavioral and motivational variable to the debate over music's usefulness in developing other, non-musical cognitive areas.

In light of the data, Fitzpatrick (2006) and Johnson and Memmott (2006) reinforce the stance that music instruction should be offered in the schools for music's sake alone. Kinney and Forsythe (2005) acknowledge that music educators prefer to establish music in the schools for its intrinsic qualities, yet recognize that this position can often require a little bending to yield to the political and other pressures placed upon them. If music is to be a part of the curriculum for its own sake, a rationale and congruent objectives need to be established for instruction that can (1) be assessed; and (2) be measured in strictly musical terms.

\section{A PHILOSOPHICAL BASIS FOR MUSIC INSTRUCTION}

For at least the last half-century, philosophers in the arts have been developing an aesthetic and philosophical base for arts instruction in the American school curriculum, in general, and music instruction, specifically. Elliott Eisner in "What is Art Education 
for?" (1958), makes a strong case for education in the visual arts that can easily be applied to an education in music.

Eisner sets forth three purposes for art education that are equally applicable to music education. First, he states that art education helps to teach students "how to see what they look at" (pg. 263). This statement could easily be rewritten to say, "Music education helps teach students how to listen to what they hear." ${ }^{\text {"4 }}$ Eisner continues on to say that students should learn to "see color and form for its own sake," "become conscious of the world in a visually stimulating way," and "create this sensation for others as well as themselves to see" (pg. 263). Eisner's second purpose for art education is to develop students' ability to solve problems creatively — solving art problems is unique in its use of intellect and emotion, yet differs little in nature from problem solving in the sciences. Finally, art education "create[s] a roundness to [the] art[s]" (pg. 264). He questions whether or not the different arts, since they are so similar, should necessarily be detached from one another.

Eisner further emphasizes that the process of creating in the arts cannot be isolated, yet should not be over emphasized. Making should not become isolated for the maker and "it is very possible [that] a student may learn how to respond aesthetically without achieving graphically" (pg. 265)—but educators must be careful not to only be appreciation or creating, a balance needs to be struck. In art education, students are encouraged to "investigate, experiment, and create;" they become more aware of the

\footnotetext{
${ }^{4}$ For the sake of brevity, I will refrain from delineating every instance in which verbs relating the visual arts may be substituted with words relating to music or aural perception in Eisner's writing.
} 
world around them; and most importantly, art education "encourage[s] the use of the mind at its optimum level" (pg. 266).

Other philosophers, such as Bennett Reimer, have put forth their own philosophies of music education. Reimer (1989) disseminates a philosophy of music education that is based primarily on the need for educators to educate the whole child, not just their fingers or vocal chords and ears-the ability to understand music is as important as being able to make it. ${ }^{5}$ If either of the two ideas exists in a vacuum, then complete music learning is not really taking place. Learning facts and listening to music does not fully engage the student in the music making process and likewise, "the focus on technical proficiency...throws the delicate balance between technique and understanding way out of kilter" (pg. 183). From this vantage point Reimer suggests music educators need not justify music in the schools for its extra-musical benefits, but that it cannot survive in the curriculum unless it can move beyond its perceived role as "just skill training; if that is all it is we can and should kiss it goodbye in the schools" (pg. 191). He therefore concludes that a short-term task for the music education profession is "to translate our philosophy into general music and performance and composition curricula that exemplify, in every detail, the value underlying them" (pg. 225). In other words, what are the specific skills and understandings that are unique to music instruction? The

\footnotetext{
${ }^{5}$ For a witty, yet powerful representation of the importance of educating all with respect to music and its intrinsic qualities, please see Bennett Reimer's essay, "Merely Listening," in B. Reimer (Ed.), Seeking the significance of music education: Essays and reflections (pp. 221-235). Reston, VA: MENC-The National Association for Music Education.
} 
National Standards ${ }^{6}$ developed by MENC - The National Association for Music Education in 1994 addressed Reimer's challenge in relatively short order.

Additionally, other philosophers have approached the importance of music education from a different perspective. For instance, Goble in What's So Important About Music Education? (2010), uses an anthropological approach and the use of symbiotics to establish a pragmatic basis for music education in America-a functional and participatory model of music making. He suggests that an American curriculum in music should serve to educate students in the purposes for creating and participating in music as is culturally prevalent in our country. Creating citizens capable of participating in the prevalent music practices of multiple cultures and communities within the United States should be the primary goal of music instruction in American schools (pg. 264).

MENC published two collections of essays by national leaders in the field of music education in the year 2000 in which the authors tackled the subjects of the National Standards and the continued development of a vision for American music education into the $21^{\text {st }}$ Century. The papers within these collections continue to place great importance on teaching more than the technical fundamentals of music in instrumental rehearsals. In Performing with Understanding: The Challenge of the National Standards for Music Education (MENC, 2000) the authors attempt to demonstrate how the National Standards can be implemented within the rehearsal process in an effort to take student understanding of music beyond the mere performance of the notes, rhythms, and dynamics written on the page. The authors' rationale is that by imparting knowledge

\footnotetext{
${ }^{6}$ The National Standards for Music Education were developed and adopted by the National Association for Music Education (MENC, now NAfME) in 1994. These will be discussed at length an upcoming section.
} 
about music upon students, students will grow an understanding of music that will help them become connoisseurs of music beyond their time in the band or orchestra class.

In Vision 2020: The Housewright Symposium on the Future of Music Education (MENC 2000), broad topics relating to the shared philosophy of music education held by the profession were addressed, including the implementation of the National Standards. The "Housewright Declaration" which is a summation of the thought and work of the authors and leaders attending the symposium sets a framework for the continued development of music education. The following are among the most pertinent declarations with regard to this study:

2. The integrity of music study must be preserved. Music educators must lead the development of meaningful music instruction and experience.

3. Time must be allotted for formal music study at all levels of instruction such that a comprehensive, sequential and standards-based program of music instruction is made available.

9. Continuing research addressing all aspects of music activity needs to be supported including the intellectual, emotional, and physical responses to music. Ancillary social results of music study also need exploration as well as specific studies to increase meaningful music listening.

10. Music making is an essential way in which learners come to know and understand music and music traditions. Music making should be broadly interpreted to be performing, composing, improvising, listening, and interpreting music notation. (pp. 219-220)

The efforts of such philosophical thought have helped to focus the goals and objectives of music education such that all components of music instruction, not merely performance are addressed in the curriculum and consequent instructional standards for music across the nation. 


\section{SUBJECTIVE WAYS OF EVALUATING MUSIC PROGRAMS}

For many years, the only means of evaluating a music program, especially an instrumental program, was through the quality of performance and subjective, sometimes arbitrary, ratings assessed at concert contests and festivals. The Kentucky Music Educators Association (KMEA) annually sponsors both marching band and concert festival events in which bands are assessed by judges. Each fall, more than 100 high school marching bands participate in many of the KMEA "sanctioned" marching band shows/contests and are assessed leading up to the State Marching Band Competitions. While rubrics are provided for judging with ratings of I (distinguished) to IV (novice) and commensurate numerical scores (KMEA, 2011b, pg. 8) are assessed for each performance, these ratings and scores are still quite subjective in nature and do not necessarily indicate a level of musical achievement or understanding beyond the performance product judged on the field. In the Spring, an even larger number of school concert bands are assessed at numerous KMEA sponsored Concert Festival sites. Adjudicators at these events assess achievement ratings of I (distinguished) to IV (novice) using a limited rubric and consequently the ratings are often quite subjectively applied. $^{7}$ This does not necessarily invalidate the ratings assessed, but it yields further evidence that an assessment of comprehensive musical understanding is not objective, practical or necessarily required in these types of events.

Since music education has been accepted into the American school curriculum, many researchers have sought to define what makes a program, and by extension, its

\footnotetext{
${ }^{7}$ The rating of "Il" or "Proficient" is described as an "excellent performance that is outstanding in some respects - All basic elements performed on an adequate artistic level with limited, but noticeable and obvious, performance and technical inconsistencies" (KMEA, 2011a, pg. 6).
} 
director successful, thereby indirectly assessing the quality of instruction in an instrumental music program. For instance, Goodstein (1987) found that 86 percent of a group of band directors classified as "successful" (subjectively classified using festival ratings, etc.) could be identified by four variables that were found to be significant $(p<$ $.01)$ predictors of group membership: the size of the marching band, the average number of freshmen entering the program, socioeconomic description of the school district, and the size of the top concert band. Interestingly, leadership variables as assessed by the LEAD-Self leadership inventory were not found to be statistically significant predictors. Examining these qualities can help define what makes a successful band director.

In a related study, Deisler (2011) sought to discover what characteristics of band programs and their directors were common to successful band programs in both high- and low-socioeconomic schools. Principals and directors in this study differed in their ratings of different program qualities with principals placing more student-centered qualities near the top of their lists; however, "band director knowledge" was rated highly by all the groups surveyed. "Band director knowledge" is quite vague and does not describe what this knowledge is. Vitter, in her study (2011) elaborates on this idea. In studying four "successful" band programs and directors in Louisiana (again, subjectively classified by festival ratings), Vitter found an interesting trend relating to the National Standards for Music Education. ${ }^{8}$ Of the nine National Standards, all but two were observed during rehearsals (one standard was discussed in a post-observation interview) by all four study

\footnotetext{
${ }^{8}$ The National Standards for Music Education were developed and adopted by the National Association for Music Education (MENC, now NAfME) in 1994. These will be discussed at length in the next section.
} 
participants. Perhaps this is the knowledge common to most successful band directors and is a vital component for excelling as an instrumental music program.

Other studies have specifically set about comparing administrator perceptions and band director perceptions of specific components of the band program. For instance, Rogers (1985) surveyed band directors and their administrators for their opinions of marching band contests finding both positive and negative aspects shared by each group. Neither believed that the educational or musical benefits of marching contests were as good for the students participating as the help they provide with public relations and recruiting. Another study comparing band director and administrator perceptions of an important component of the instrumental music classroom — grading practices—was examined by McCoy (1991). In his study, a significant difference was found between directors grading practices and administrator recommendations. This research found that administrators gave more weight to cognitive and performance assessment, while the band directors focused more heavily on attendance and behavior criterion. The conclusion drawn by McCoy stated band directors have two types of grading criteriathe ideal and the pragmatic. The former is more comprehensive and represents what band directors want to use, the latter is ends up being used because they may be too busy to grade on a cognitive basis, among other reasons. Unfortunately, in the quest for finding a means of objectively evaluating music instruction as an integral part of the curriculum, principals had, for a long time, only a subjective, performance and noncontent based means of evaluating a music or band program. 


\section{THE NATIONAL STANDARDS IN MUSIC EDUCATION}

As an outgrowth of the need to objectively assess music, yet still remain true to the established philosophy of music education as an aesthetic component of education, many organizations developed standards for the content and instruction of music that have subsequently been adopted by some states. MENC - The National Association for Music Education (now NAfME) was among the first to establish standards for all grade levels and types of music instruction following the passage of the Goals 2000: Educate America Act (H.R. 1804) by Congress in 1994. Goals 2000 provided a framework for a nationwide reform of the educational system. Among the many purposes of Goals 2000, one goal was the development of content and performance standards every student should be able to achieve. This legislation also established the arts as one of the many curricular areas in which every student should be educated and be able to demonstrate proficiency.

The impetus for the adoption of a standards based curriculum can be further traced to 1983 with the National Commission on Excellence in Education's report to the Secretary of Education, A Nation at Risk. The Commission cited America's lagging performance on international comparisons of student achievement compared with the rest of the highly-developed world as well as large numbers of functionally illiterate Americans, and falling scores on standardized aptitude tests (i.e., SAT) between 1963 and 1980 as some of the greatest indicators of America's risk. Recommendations made by the commission include curriculum reform along with higher standards of achievement, the adoption of a nationwide system of standardized measures of achievement, and, importantly for music and arts educators, the provision of rigorous coursework for high school students in areas that "advance students' personal, educational, and occupational 
goals, such as the fine and performing arts. .." (para. 40). These courses should complement the "New Basics" (in curricular content set forth in the Commission's recommendations) and they should "demand the same level of performance as the Basics" (para. 40).

In The School Music Program: A New Vision (MENC, 1994), the high quality of music programs across the nation is lauded but criticized as being narrowly focused on Western music and lacking clear goals and systems for assessment while sometimes only reaching a small number of students (especially in secondary school instrumental music programs). The stated purposes of this document are to "create a coherent vision of what it means to be educated in music," "provide a foundation for building a balanced, comprehensive, and sequential curriculum in music," and "to provide specific assistance in improving the music curriculum" (pg. 2).

The Standards set forth by MENC are developed to be used as a blueprint,

Designed to reflect a national consensus concerning the highest-priority skills and knowledge young people should have acquired upon exiting grades 4, 8, and 12 . They apply to every student through grade 8 and to every student enrolled in music beyond grade 8 . Although music instruction in school is important to the development of those students who are talented in music, its primary purpose is to improve the quality of life for all students by developing their capacities to participate fully in their music culture. (pg. 2)

These standards emphasize skills in analysis, evaluation, and synthesis above and beyond the performance skills so heavily emphasized in music programs, especially instrumental and vocal music program rehearsals. Furthermore, it is indicated that all courses, even performance based courses, "should provide opportunities for creating, 
performing, listening to, and analyzing music, in addition to its specific subject-matter" (pg. 21).

The 9 National Standards for Music Education as set forth by MENC in The School Music Program: A New Vision are:

1. Singing, alone and with others, a varied repertoire of music.

2. Performing on instruments, alone and with others, a varied repertoire of music.

3. Improvising melodies, variations, and accompaniments

4. Composing and arranging music within specified guidelines.

5. Reading and notating music.

6. Listening to, analyzing, and describing music.

7. Evaluating music and music performances.

8. Understanding relationships between music, the other arts, and disciplines outside the arts.

9. Understanding music in relation to history and culture.

Additionally, noted music teacher educator Charles Hoffer (2009) firmly states that "gathering students together in a class and calling it 'music' does not ensure that music learning will take place" (pg. 113). Further, he articulates the need for music educators to get below the surface of the music being learned in a rehearsal or a class in order to guarantee that students are gaining an understanding of pertinent subject matter-singing one song after another does not necessarily help facilitate the learning process. Effective music instruction, according to Hoffer, will strive to attain a balance between making music and understanding and valuing music (pg. 119).

A problem in the curriculum for performing ensembles is that the directors frequently have the freedom to select the content and materials that will be covered during instruction based on their professional expertise to accommodate the ensemble's 
situation as well as their own preferences. Guidance from school administration, on all levels, and curriculum guides are not frequently encountered in the public schools; the National Standards are there to offer help and guidance in the development of a curriculum and instruction that foster a deeper understanding of music. This does not mean that each music class should devote equal attention to all nine standards, but a "reasonable inclusion" of as many standards as appropriate to the content being studiedevery class or rehearsal need not include all standards and different courses need not contain equal amounts of each standard (Hoffer, 2009, pg. 127). For example, band rehearsals should contain a modicum of Standards 3 and 4 (creating music) and Standards 8 and 9 (understanding interrelationships with music) in addition to the daily focus on Standards 1, 2, and 5 (performing). Each standard need not be covered each day in rehearsal, but it is possible to include some of each standard over the course of a year, month, or even a week. The National Standards exist to help music educators develop music instruction that leads to a greater understanding of music, not simply the development of flawless, yet possibly mindless performances.

Likewise, Fallis (1994) supports the idea that the music curriculum should consist of a basic core of classes, in which all students are able to participate thereby ensuring they will receive instruction in as many of the standards as possible. From this core, performing ensembles can provide an opportunity for enrichment in the performance standards. When compared to the existing paradigm, this provides a more solid foundation for ensuring that the standards, which in Fallis' opinion "describe exactly what we already do, and in some instances, what we do not do" (pg. 28), are taught in the most comprehensive manner possible. 
Other organizations have also developed standards for music instruction. The American School Band Directors Association (ASBDA), for instance, has developed a curriculum guide of its own with six standards-similar to the MENC National Standards - specific to instrumental music instruction. Paralleling the National Standards, the ASBDA standards for instrumental music instruction state that,

After participating in a school instrumental music program through the $12^{\text {th }}$ grade, the student will:

1. Demonstrate the language art of reading and interpreting music notation;

2. Perform music independently and with others;

3. Describe, analyze, and create music;

4. Evaluate music by using critical thinking and listening skills;

5. Demonstrate a knowledge of music history and cultural heritage;

6. Participate in the cultural/musical life of the community through involvement in local and regional music/arts opportunities. (ASBDA, 1997, pg. 14)

In the past, however, some have argued that educational objectives can be a hindrance to learning in the arts. Eisner (1967) posed thought provoking questions about educational objectives helping or hindering the learning process in the arts however, one can argue that the standards in music answer some of his questions. He initiates his argument by outlining the positives of objectives in education. First they provide goals for the education process to aim for. Second, after the goals have been selected, content can be decided upon and organized in a manner appropriate to the achievement of the goals. Finally, educational objectives facilitate the assessment and evaluation of instruction. From this point, Eisner discusses why he believes such objectives can also hinder instruction. 
He argues against the use of educational objectives by stating that, while it is possible to reasonably estimate the result of instruction, it may not always be accurate to limit the potential outcomes to what is expected. A natural outcome of instruction due to all variables could make it possible for new and differing outcomes to emerge- "the dynamic and complex process of instruction yields outcomes far too numerous to be specified in behavioral and content terms in advance." His next point relates to the inability to apply content and behavioral objectives and outcomes to all subjects equally; some subjects more readily allow for the reasonable application of educational objectives and outcomes, the arts is not one of these. He contends that,

In the arts, such specification is frequently not possible, and when possible may not be desirable. In a class in mathematics or spelling, uniformity of response is desirable.... In the arts and in subject matters where, for example, novel or creative responses are desired, the particular behaviors to be developed cannot be easily identified. Here curriculum and instruction should yield behaviors and products which are unpredictable. (pg. 554)

Finally, Eisner posits that objectives do not account for the need to make a judgment versus the application of a standard, e.g. criticizing a poem versus writing a sentence or completing a math equation. Essentially, the standards that are used to measure educational objectives can exclude the modes of achievement that cannot be measured (pg. 557). While Eisner's argument may have some valid points, they can certainly be addressed, to an extent, by the comprehensive nature of the National Standards developed by MENC. In an effort to balance performance and content in the music classroom as well as address some of the concerns shared by Eisner, and others, about curriculum and assessment, many states have adopted standards and congruent 
assessments of their own, similar to or often related to the National Standards established by MENC.

\section{KENTUCKY'S CORE CONTENT FOR ASSESSMENT}

In 1990 Kentucky adopted a widespread reform of the public education system. The Kentucky Education Reform Act (KERA), H.B. 940, is the result of the Kentucky Supreme Court's decision in Rose vs. Council for Better Education (1989), in which local schools boards and students, among others, challenged of the "equity and adequacy of school funding in the state" (WKU, 2012, para. 3). The Kentucky Supreme Court viewed its decision as a springboard for Kentucky to begin a new period of educational opportunity. "KERA created a structure to redefine the education system by providing learning goals along with procedures to assess them" (WKU, 2012, para. 5).

Section 2 of KERA specifically lists the arts as an area in which students should be educated. ${ }^{9}$ Section 3 assigns a Council on School Performance Standards to frame the six learner goals (also established in Section 3) in measurable terms to define student achievement. The learner six goals are listed below. The results of this council's work are still evident today in Kentucky's Core Content for Assessment 4.1. Finally, of importance to this study is the development of a statewide system for "performancebased assessment... [and] to ensure school accountability for student achievement of the goals set forth in Section 2" (KERA, 1990).

\footnotetext{
9 "Sufficient grounding in the arts to enable each student to appreciate his or her cultural and historical heritage." (KERA, 1990)
} 
The six Learner Goals set forth in Section 3 of KERA are:

(b) Schools shall develop their students' ability to:

1. Use basic communication and mathematics skills for purposes and situations they will encounter in life;

2. Apply core concepts and principles from mathematics, the sciences, the arts, the humanities, social studies, and practical living studies to situations they will encounter throughout their lives;

3. Become a self sufficient individual;

4. Become responsible members of a family, work group, or community including demonstrating effectiveness in community service;

5. Think and solve problems in school situations and in a variety of situations they will encounter in life; and

6. Connect and integrate experiences and new knowledge from all subject matter fields with what they have previously learned and build on past learning experiences to acquire new information through various media sources. (KERA, 1990)

As previously mentioned, a result of KERA was the establishment of content standards for all content areas, including music. Known as the Kentucky Core Content for Assessment (CCA; currently in version 4.1, adopted in August 2006), the content standards, listed in Appendix A, were assessed using paper and pencil measures of achievement until these measures were suspended in the arts and Humanities in 20082009 school year as a result of Senate Bill lin March of 2009. Senate Bill 1 revised the accountability testing and assessment system used in Kentucky set forth by KERA almost 20 years earlier. The most important change made was the adoption of a new system for authentic assessment in the arts and Humanities--the program review.

The Kentucky Department of Education defines the Program review as "an ongoing, year-round, reflective process" (KDE, $2011 \mathrm{~b}$, Section 1, pg. 3) that should, ideally, 
engage all school staff in program improvement. Among the four purposes stated for the adoption of the program review system of assessment and accountability is to "[allow for] student demonstration of understanding beyond a paper and pencil test" (KDE, $2011 \mathrm{~b}$, Sec.1, pg. 3). In other words, the goal of the program review system is to allow for performance and creation in the arts to be assessed authentically. This is instead of relying standardized tests which, more often than not, simply include multiple choice and open-response questions about music history and theory.

Educators are encouraged, under the new system, to use their "professional judgment" when gathering the evidence required to substantiate the assessments made during the review process (Tungate, 2010). This evidence is then assessed and graded using a rubric (KDE, 2011a) which, incorporates standards for Curriculum and Instruction, Formative and Summative Assessment, Professional Development, and Administrative/Leadership Support and Monitoring. Importantly, for the purpose of this study, the rubric requires, within the Curriculum and Instruction standard, that instruction is (1) aligned with State and National content standards (Demonstrator 2) and that, (2) instruction incorporates opportunities for the creation, performing, and responding to the arts within instructions (Demonstrator 3). 


\section{TEACHER PERCEPTIONS OF THE NATIONAL STANDARDS}

Since the development of the National Standards in music, studies have been done to examine the perceptions teachers and others have of their ability to implement the standards. For instance, Byo (1999) examined the perceptions music teachers and general classroom teachers hold with regards to their ability to implement the standards.

One of her most important findings is that many classroom teachers view music instruction as a specialist's domain. Many of the fourth grade generalists surveyed placed more importance on National Standards 8 and 9 (understanding the interrelationships with music) than the music specialists surveyed. Incidentally, the music specialists rated Standards 1 (singing), 6, and 7 (listening/analyzing and evaluating) highest. Music teachers felt a responsibility to implement all of the standards and generalists did not feel a similar responsibility_even Standards 8 and 9 were not rated above "neutral" when surveyed. Byo concluded that administrators should be aware of the limitations facing specialists given that they are generally believed to be, and in actuality are, responsible for implementing all of the standards by themselves. It seems reasonable then, that they may not have the same assessment systems built in at the school-level that other content areas have. Two similar and related, yet earlier studies support Byo's conclusions that music is perceived as a specialist's domain.

The view of music instruction as the specialist's domain is reinforced by Bresler (1993) and Saunders and Baker (1991). In a year-long qualitative study of school instruction in two Illinois communities, Bresler found that outside of the music classroom, music instruction was limited. Music is commonly used for the illustration of 
extra-musical subject matter, a change of pace or transition, and as a background activity. In very few instances in the general classroom was music listened to and appreciated for what it is, rather than how it can help learning other subjects. One can follow this trend all the way back to the first section, regarding "music for math's sake." Bresler determined that a general lack of knowledge, resources, and appropriate structures coupled with an educational climate that puts pressure on academic content areas are responsible for this lack of appreciation of music outside of the music classroom.

In a related study, Saunders and Baker (1991) surveyed preservice and inservice K-5 classroom teachers $(N=300)$ regarding their perceptions of music skills and understandings that are useful in the early-childhood and the elementary classroom. All of the teachers surveyed taught at schools where regular music instruction was provided for students and as a result found that 47 percent of the teachers surveyed did not incorporate music into classroom instruction because a music specialist is present. Another important finding is that the quantity of music instruction in the classroom decreased as students' age increased -90 percent of kindergarten teachers incorporated music into the classroom while only 25 percent of fifth grade teachers did. The majority of participants had studied topics appropriate to teaching music in the general classroom, for example, "selecting appropriate songs" or "developing movement activities." In spite of this data the authors found and conclude that classroom teachers generally see teaching as the specialists job, they do not want to be supplemental music teachers, and that when music is used it is used as a "break" or a "transition"- similar to what Bresler and Byo had discovered. Still, others have sought to understand the perceptions of classroom teachers about elementary general music instructional goals, in general. 
Abril and Gault (2005) found that elementary classroom teachers had generally positive views of general music instructional goals. Preservice $(n=208)$ and inservice $(n=73)$ were asked to respond using a Likert-scale to instructional goals in five areas: entertainment/recreation, expressive/creative, interdisciplinary, musical, and sociocultural. Both groups had generally positive views of the outcomes of instructional goals; preservice teacher means were higher for all of the outcomes, except the musical outcomes, which the inservice teachers generally rated higher. No mean scores for either group fell below the midpoint indicating that there is an overall support for the goals of music education even if the preservice teachers valued the "entertainment/recreational" goals highly. This data seems to support the idea that many teachers value music instruction, whether or not they teach it in the general classroom, yet they seem to support the idea of music instruction for "entertainment/recreation," "interdisciplinary," or "sociocultural" purposes relatively as much as for its "expressive/creative," and "musical" goals.

A study by Bell (2003) found that music teachers are generally aware of the National Standards but may lack the support systems to apply all the standards at the district or school level. Through an exit survey of students $(N=14)$ in a graduate level music education elementary methods course in New York, she found that 71 percent of the teachers worked in districts that had adopted standards for music instruction. She also found that 29 percent of respondents were encouraged to incorporate standards into their lessons and 71 percent of teachers made an attempt to incorporate the standards into instruction. Very few respondents indicated a difficulty with implementing standards 6 (listening) and 5 (reading and notating music). However there were some 36 percent of 
respondents that indicated a lack of training to implement standard 3 (improvising). A few others indicated a desire for more information regarding the implementation of standards 8 (relation to other arts) and 9 (relation to history and culture). The results of the study seem to indicate there may still be a gap in the training or ability of teachers to implement some of the National Standards.

It is unclear whether the adoption of standards for music instruction has created the feeling amongst general educators that music needs to be taught by a specialist, despite apparent support for the goals of music instruction, or not, but it appears that as long as music is in the curriculum, specialists will be needed to ensure that all the standards and goals of music are being met. Additionally, as long as music specialists are responsible for school-wide instruction in the arts, there may be a need for unique assessment systems for the standards in music to be assessed, different from those enjoyed by teachers in other content areas. Bell's study (2003) may indicate that there are still music teachers that may have difficulty implementing the standards nearly a decade after their adoption by MENC. If there are certain standards that are difficult to implement or teachers consciously omit because of a perceived ignorance of the content, perhaps school administrators are witnessing the same gaps in instruction. 
THE STATE OF MUSIC INSTRUCTION IN THE SCHOOLS: THE PRINCIPAL'S PERSPECTIVE

Two studies by Abril and Gault have generated a profile of music programs and instruction across the United States. One study (2006) examines principal perceptions of the elementary music program and the other (2008) studies the perceptions of secondary school principals regarding music instruction. In their 2006 study, Abril and Gault found that elementary principals were "generally satisfied" with their music program's ability to meet current educational standards. They also found that there is a significant $(p<.01)$ difference between what they currently observed in instruction and what their ideal vision of music instruction with regards to specific music learning outcomes and broad educational goals. Of note were the principal ratings of:

"listening attentively" which had the highest mean and lowest standard deviation for both the current and ideal conditions of instruction;

"create and compose" had the lowest mean and highest standard deviation in both conditions;

"performing" was rated second in the current condition and fourth for the ideal condition, signaling an inconsistency between what principals are observing and what they would like to happen;

and "understanding music in relation to other subjects" which was rated fifth overall for the current condition but would ideally be rated second, again displaying a discrepancy between what "is" and what "should be" present in the ideal situation. 
Of the broad educational goals assessed, "fostering creative thinking" was rated the lowest in the current condition. The highest rated goals for the current condition were "developing creativity" and "transmitting cultural heritage." For the ideal condition, "developing creativity" was rated the highest showing an agreement between what the music programs are currently doing and what the principals would ideally like the programs to do. However, "create and compose" had the lowest mean of the musical outcomes in the current condition. This may seem to indicate that there is little actual creativity happening in the music class. The authors speculate that this may be due to the principals' perceptions of performing as being creative.

In addition to surveying the current and ideal perceptions of musical learning outcomes and broad educational goals, Abril and Gault also collected attitudes regarding the biggest inhibitors to music instruction in their schools. The most "strongly negative" and "negative" responses were toward budgeting, No Child Left Behind (NCLB), scheduling, and standardized tests. On the opposite side of the spectrum, positive impacts on music instruction were students, parents, and the music teacher.

Similarly, in the study surveying secondary school principals (2008), Abril and Gault asked principals to rate how they believed their music programs were able to facilitate learning with regards to seven music learning outcomes and 13 broad educational goals - but only in the current condition. Important to note is that middle schools $(58 \%)$ generally required music more often than high schools (18\%). Also, a significant $(p<.001)$ difference was found between the number of music teachers at rural and suburban schools. Significant $(p<.001)$ differences were also found between the number of music course offerings between rural schools and both suburban and urban 
schools, as well as when compared based socioeconomic status. The most common music courses offered in the secondary schools surveyed are band $(93 \%)$, chorus $(88 \%)$, jazz/rock ensemble (55\%), general music (45\%), orchestra (42\%), and theory $(40 \%)$. Other courses such as guitar, keyboard, or technology are offered in fewer than 20 percent of the school surveyed.

Like the results of the elementary study from 2006, secondary principals had generally positive opinion of the musical learning outcomes. Also, like the elementary survey, "performing" was rated the highest (it was second highest in the elementary survey) and "listening attentively" was rated very highly; "create and compose" had the lowest mean and greatest standard deviation. Again, there was a contradiction found in the broad educational goals-_ "developing creativity" was rated third highest among the broad educational goals but within the musical learning outcomes, "create and compose" was rated at the bottom of the list. Again, the authors suggest that it is possible that principals consider "performing" a "creative" activity and that principals, possibly, cannot witness the composition process like they can a concert or rehearsal.

Finally, substantial inhibitors to the music programs in secondary schools were indicated to be NCLB and standardized testing; respondents were divided among budgeting/finance and scheduling as a hindrance to their programs. Secondary principals also indicated that parents, students, music teachers, other teachers, and the school board were all positive influences on the music program, again, similar to the results of the elementary study. What is unique about the above mentioned studies is their focus solely on school administrators' perceptions of the music programs and instruction at their 
schools. It stands to reason, that music educators should actively seek out the perceptions of their administrators regarding their music program and the content being taught. 


\section{CHAPTER 2}

\section{RESEARCH QUESTIONS}

\section{STATEMENT OF THE PROBLEM}

The purpose of this study is to survey the perceptions of secondary school administrators and band directors regarding the implementation of Kentucky's Core Content for Assessment 4.1 in music in the band programs at their schools. Band director perceptions will be surveyed to examine any differences between what directors are or are not teaching and what administrators are observing. This study will be a partial replication of the work of Abril and Gault (2008) specific to the State of Kentucky.

\section{RESEARCH QUESTIONS}

To survey secondary school administrator and band director perceptions regarding the implementation of Kentucky's Core Content for Assessment 4.1 in music in the band programs at their schools, the following questions will be considered:

1. What are the perceptions that secondary school administrators and band directors hold regarding the implementation of KY CCA 4.1 in the rehearsals of their band programs? 
2. How do administrators observe and assess whether or not their band program is meeting the standards set forth in KY CCA 4.1 ?

3. How do band directors implement the content specified in KY CCA 4.1 within the rehearsal process; what techniques have they discovered that work?

These three research questions will help guide a discussion of the similarities and differences between what administrators are observing and what band directors are teaching in the band class. This study will use mixed methods within a questionnaire/survey completed by the participants.

\section{EXPECTATIONS OF THE RESULTS}

The following results are expected from the data collected in this study. First, positive responses from both band directors and administrators to the Likert items of the survey, similar to the results obtained by Abril and Gault $(2006,2008)$ are expected. Additionally, it is expected that standards relating to composing or creating music and improvisation will be perceived to be the least successfully implemented standards, while the standards relating to performing will be the most successfully implemented standards, again based on the results of Abril and Gault (2006, 2008), and Bell (2003). Next, it is expected that administrators are observing the implementation of KY CCA 4.1 through simple observation of the rehearsal or classroom. And finally, it is projected that there will be differences between what administrators perceive and what band directors are teaching, both quantitatively and qualitatively. 


\section{CHAPTER 3}

\section{STUDY DESIGN}

\section{SURVEY INSTRUMENT}

This study used mixed methods within a questionnaire/survey. The survey was developed after reading through related literature and consulting the Kentucky CCA 4.1 document containing the standards for music instruction. The survey was subsequently tested by graduate students, and practicing band directors in Kentucky. In March 2012, participants received an email containing a hyperlink to the survey hosted by surveygizmo.com to be completed online. The survey was closed 18 days after the initial emailing.

The survey (Appendices D \& E) was divided into four sections: the consent document, demographics, the survey, and a component asking about interest in a potential follow-up interview related to the study results. Administrators and band directors received similar surveys that were modified to address each specific group.

The informed consent document was combined with a preamble on the first page of the survey. In order to access the actual survey questions, participants were required to check the box corresponding to "yes" in regards to the statement, "Do you agree to participate in the study, 'Administrator and Band Director Perceptions of the Implementation of KY Core Content for Assessment in Music, ' as administered by David 
Buchholz, student in the University of Louisville School of Music?" A negative response took participants to the final page of the survey thanking them for their time--they did not see any other component of the survey.

The demographic section of the survey included ten required and non-identifying questions regarding music instruction in each school, school population, school location, music courses offered in the curriculum, and music staff. Slightly different information was requested from each group, therefore the exact questions and wordings varied between the administrator and band director surveys.

The survey itself (Appendices D \& E) contained a component for middle school administrators and band directors and a component for high school administrators and band directors. The survey was designed to take participants to the specific set of questions based on their response to Question 5, "What grade levels does your school serve?" Participants who answered "other" or "P-12," were asked to further specify either " $6-8$ " or "9-12" based on what grade level they felt most comfortable assessing ("P-12" respondents) or which grade levels most closely aligned with the grade levels served by their school ("other" respondents).

Once participants had been directed by the survey to a specific grade level, they were asked to provide responses to ten statements drawn directly from KY CCA 4.1 for either middle school or high school using a Likert scale (strongly agree to strongly disagree, five points-including a selection for "unsure"). Accompanying each Likert item, an optional open response field was provided to allow participants to provide an 
example of how that CCA 4.1 standard was observed (administrators) or implemented (band directors).

After completing the survey questions, participants were asked if they were "interested in or willing to participate in follow-up questions regarding this study. . " Participants that provided a positive response were asked to provide contact information to be reached for follow-up questions. However, due to time constraints, no follow-up contact was implemented by the researcher. A negative response took participants to the final page of the survey thanking them for their time.

\section{PARTICIPANTS}

In order to provide a cross section of Kentucky secondary administrators and band directors, yet maintain a manageable sample size, the participants in this study were limited to those administrators and band directors who worked in metropolitan Louisville, Kentucky and the surrounding northwest-central region of the state. Since private schools are not subject to the same testing and curriculum requirements as public schools, administrators and band directors at private schools were not eligible for inclusion in this study.

To arrive at the sample surveyed in this study, a hypothetical 70 mile radius was drawn around the city of Louisville using the downtown district as the approximate focus. All county schools located in a county with its seat located inside of the inclusion radius were eligible for inclusion in the study. All independent schools (i.e., local or city schools) where the locale served is located within this 70 mile radius were included as 
well. There are two dependent school systems in Kentucky serving military installations.

One, the Fort Knox Dependent Schools, lies within the 70 mile radius for inclusion.

However, this school system was excluded from the study due to an uncertainty on the part of the researcher about school governance and regulations in this school system.

These criteria resulted in identifying 31 county school systems (slightly more than a quarter of all counties in Kentucky) and 10 independent school systems. Within these school systems, there are a total of 70 high schools, 98 middle schools (or primary/intermediate schools serving grades 6-8), and 4 schools serving a combination of grades K-12 or 6-12. As a result, 158 administrators and total of 148 band directors were contacted for participation in the study. ${ }^{10}$

\section{RECRUITMENT AND GENERAL STUDY PROCEDURES}

Participants were recruited via email. A cover letter (Appendices B \& C) was written to specifically address each group of participants and was included in the email with the hyperlink to the study. The survey was administered and available for completion for 18 days in March 2012. In the second week of study administration, a follow-up email (Appendices B \& C) was sent to participants as a reminder to complete the survey. After the survey administration period was closed, data was provided, in a report, by the online survey program and subsequently analyzed by the researcher.

\footnotetext{
${ }^{10}$ The number of administrators and band directors contacted for participation in the study may not add up to the number of schools in the inclusion radius due to (a) administrators that serve both middle and high school grades, (b) band directors that serve both middle and high school grades, (c) inability of the researcher to locate the names and email addresses for the administrators at some schools. Each individual only received one invitation/survey to complete.
} 


\section{CHAPTER 4}

\section{RESULTS}

\section{DEMOGRAPHICS}

A total of 158 secondary school administrators were contacted for participation in the study. One email bounced back after the initial mailing. Therefore, a total of 157 administrators were contacted and 21 returned complete surveys, for a response rate of 13.4\%. One hundred and forty-eight band directors were initially emailed about the study and two emails were returned by the email server. Of the 146 band directors that successfully received an email for participation in the study, 18 surveys were completed for a response rate of $12.3 \%$. Additionally, one administrator replied to the email invitation to the survey and indicated that his school did not have a band director.

Of the 21 administrator surveys returned, one participant did not consent to participate in the study. Therefore the total number of administrators for which data was collected is 20. Eighteen of the band directors contacted consented to participate, however one respondent indicated that they did not teach band at the secondary school level. As a result, demographics from their survey were collected, but data from their survey was not recorded, yielding 17 band directors for which survey data was collected. The total number of responses for the study, in which useable survey data was collected, is 37 or $12.2 \%$. 
The majority of respondents to both the administrator and band director surveys worked at middle schools or served middle school aged students. Sixty-five percent of administrators and $77.8 \%$ of band directors fit these criteria. Table 1 shows the distribution of grade levels served by all respondents. In order to produce a sample large enough to establish meaningful data in this study, all administrators will simply be considered as one group—-"secondary school administrators"-and all band director responses will be considered as a single group—-"secondary band directors."

Table 1

"What grade levels does you school serve?"

\begin{tabular}{lcccccccc}
\hline & \multicolumn{8}{c}{ Grade levels served } \\
\cline { 2 - 8 } \multicolumn{1}{c}{ Group } & $6-8$ & $(\%)$ & $9-12$ & $(\%)$ & P-12 & $(\%)$ & other & $(\%)$ \\
\hline Administrator $(n=20)$ & 11 & $(55)$ & 6 & $(30)$ & 0 & $(0)$ & 3 & $(15)$ \\
Band Director $(n=18)$ & 13 & $(72.2)$ & 3 & $(16.7)$ & 1 & $(5.6)$ & 1 & $(5.6)$ \\
\hline
\end{tabular}

Information gleaned from the demographics section of the survey indicates that approximately two-thirds of schools require some form of music instruction. There appears to be a discrepancy about who sets the requirements for music instruction in the schools, based upon the responses of the administrators compared to those of the band directors. Half of administrators indicated that the Site Based Decision Making Council (SBDM) was responsible for setting music requirements while only $22 \%$ of band directors indicated that the SBDM was responsible for these requirements. This is the same percentage of band directors that indicated that the music teacher was responsible for this decision. Band directors were $400 \%$ more likely to respond that the music teacher was responsible for determining the requirements for music instruction than 
administrators. However, this apparent discrepancy may be the result of a low response rate; it is possible that the band directors surveyed were not all from the same school district as the administrators that responded to the survey, and these disparate results could simply be an effect of working in different school systems.

Table 2

School Demographics (A): Enrollment and Location

\begin{tabular}{|c|c|c|c|c|c|c|}
\hline \multirow[b]{2}{*}{ Group } & \multicolumn{2}{|c|}{ School enrollment } & \multicolumn{4}{|c|}{ Location } \\
\hline & Mean & SD & Urban $(\%)$ & $\begin{array}{l}\text { Sub- } \\
\text { urban }\end{array}$ & $(\%)$ & Rural (\%) \\
\hline Administrator $(n=20)$ & 727.9 & 395.13 & $(30)$ & 6 & (30) & $(40)$ \\
\hline Band Director $(n=18)$ & 793.67 & 366.06 & $(27.8)$ & 6 & $(33.3)$ & $(38.9)$ \\
\hline
\end{tabular}

School Demographics (B): Socioeconomic Status

\begin{tabular}{lcccccccccc}
\hline & \multicolumn{6}{c}{ Percentage of students receiving free and reduced price lunch } \\
\cline { 2 - 10 } Group & $<10 \%(\%)$ & $11-25 \%(\%)$ & $26-50 \%$ & $(\%)$ & $51-75 \%$ & $(\%)$ & $>75 \%(\%)$ \\
\hline Administrator $(n=20)$ & 1 & $(5)$ & 3 & $(15)$ & 6 & $(30)$ & 7 & $(35)$ & 3 & $(15)$ \\
Band Director $(n=18)$ & 0 & $(0)$ & 1 & $(5.6)$ & 10 & $(55.6)$ & 6 & $(33.3)$ & 1 & $(5.6)$ \\
\hline
\end{tabular}

Table 2 shows the responses regarding school size, location, and socioeconomic status for administrators and band directors. Responses were obtained from administrators and band directors at schools of all sizes and roughly equal numbers of urban, suburban, and rural locations. Both band directors and administrators generally work in schools where between $26 \%$ and $75 \%$ of the student body receives free or reduced price lunches. The schools represented in this survey generally employed two full-time music teachers with one responsible for teaching band (Table 3). Interestingly, four administrators expressed the full-time equivalency (FTE) of the number of 
specialists teaching band in decimals. The number of FTE band directors at these four schools ranged from 0.13 to 1.5 and indicates that many band directors teach courses beyond the scope of the band rehearsal. The information in Table 4 confirms this idea.

Table 3

Average Number of Music Specialists Teaching in Each School and the Number of Music Specialists Teaching Band

\begin{tabular}{lcccccc}
\hline & \multicolumn{2}{c}{$\begin{array}{c}\text { Music Specialists at } \\
\text { Each School }\end{array}$} & & \multicolumn{2}{c}{$\begin{array}{c}\text { Music Specialists } \\
\text { Teaching Band }\end{array}$} \\
\cline { 2 - 3 } Group & Mean & SD & & Mean & SD \\
\hline Administrator $(n=20)$ & 1.83 & 0.71 & & 1.03 & 0.44 \\
Band Director $(n=16)$ & 2.17 & 0.92 & & 1.06 & 0.25 \\
\hline
\end{tabular}

The size of the band program is the last demographic of interest to this study. Band directors provided a response to this request. This enrollment information was subsequently compared to the school sizes reported by the band directors to arrive at an average proportion of students served by the band programs represented in this study. Table 5 shows the mean school enrollments and band program enrollments (provided by the band directors) as well as the mean proportion of students served by band programs. 
Table 4

Other Courses Taught by Band Directors

\begin{tabular}{lcc}
\hline Course & $\begin{array}{c}\text { Number of } \\
\text { responses }\end{array}$ & $\%$ \\
\hline Band & 17 & 94.4 \\
$\begin{array}{l}\text { Percussion } \\
\text { Ensemble }\end{array}$ & 6 & 33.3 \\
Jazz Band & 6 & 33.3 \\
General Music & 5 & 27.8 \\
$\begin{array}{l}\text { Music Theory or } \\
\text { History }\end{array}$ & 5 & 27.8 \\
$\begin{array}{l}\text { Piano/Keyboard } \\
\text { General Music } \\
\text { within an Arts \& }\end{array}$ & 3 & 16.7 \\
Humanities Course & 2 & 11.1 \\
Choir/Chorus & 2 & 11.1 \\
Guitar & 2 & 11.1 \\
Orchestra & 0 & 5.6 \\
Other & 0 \\
\hline Note. The numbers and & 2 & 0 \\
\hline
\end{tabular}

Note. The numbers and percentages may note add up to 18 or $100 \%$, respectively, due to respondents being able to select as many options as apply (e.g., 5 band directors or $27.8 \%$ also teach a general music class). 
Table 5

Proportion of School Population Enrolled in Band as Reported by Band Directors

\begin{tabular}{lll}
\hline & Mean & SD \\
\cline { 2 - 3 } Size of Band Program $(n=17)$ & 134.41 & 61.09 \\
Size of School $(n=17)$ & 818.29 & 361.62 \\
Proportion of \\
$\begin{array}{l}\text { School Served by } \\
\text { the Band Program } \\
\text { ( } n=17)\end{array}$ \\
$\begin{array}{l}\text { Note. One set of responses was excluded because it } \\
\text { contained a value of " } 0 \text { " for the size of the band } \\
\text { program. }\end{array}$
\end{tabular}

While the preceding demographics are not the primary focus of this study, and it is not this researcher's intent to assess the health of music programs in Kentucky based on the demographics provided, they describe the respondents and their schools and may help discover or potentially provide an explanation for some of the results of the survey.

\section{RESEARCH QUESTION 1}

What are the perceptions that secondary school administrators and band directors hold regarding the implementation of KY CCA 4.1 in the rehearsals of their band programs?

Administrator and band director perceptions of their band programs' implementation of Kentucky CCA 4.1 was measured using a Likert scale. Due to a low response rate, especially among high school administrators ( 7 responses) and high school 
band directors (3 responses), aggregate data was used to do a simple comparison of administrators and band directors. Due to a difference in the verbiage and content of the middle school standards and high school standards, the 10 standards for middle school and $9^{11}$ standards for high school were matched to create five "content themes." For instance, the performance standards for middle school and high school were matched. The three middle school standards for talking about or describing music were combined with the similar standard for high school. Table 6 outlines the content themes and the corresponding standards. As you can see from Table 6, some of the standards may be weighted more toward middle school responses or high school responses based on the number of standards from each grade level in each content theme. Additionally, there is one unique content standard for each high school and middle school.

Participants were asked to rate their agreement with statements drawn directly from the KY CCA 4.1 standards in music using a Likert scale. Table 7 displays the mean scores and standard deviations for the administrator and band director responses for each content theme on the Likert scale component of the survey. All of the means were positive for both the administrators and band directors; however the administrator responses were more positive than the band directors'.

\footnotetext{
${ }^{11}$ Upon completion of the survey and analysis of the resultant data, the researcher discovered that a middle school standard had mistakenly been added to the high school standards in the survey. This yielded a total of 10 high school Likert scale items on the survey, when in fact there should have only been 9. The data from question 23 was subsequently excluded from analysis and all of the data presented here reflects this change.
} 
Table 7

Administrator and Band Director Ratings of the Implementation of KY CCA 4.1

\begin{tabular}{|c|c|c|c|c|c|c|c|c|c|c|}
\hline \multirow[b]{2}{*}{ Group } & \multicolumn{2}{|c|}{$\begin{array}{c}\text { Describing } \\
\text { Music }\end{array}$} & \multicolumn{2}{|c|}{ Humanities } & \multicolumn{3}{|c|}{$\begin{array}{c}\text { Creating and } \\
\text { Composing }\end{array}$} & \multicolumn{3}{|c|}{ Improvising } \\
\hline & $n$ Mean & $\mathrm{SD}$ & $n$ Mean & $\mathrm{SD}$ & $n$ & Mean & $\mathrm{SD}$ & $n$ & Mean & SD \\
\hline Administrator & $46 \quad 4.39$ & .53 & 4.2 & .69 & 33 & 4.03 & .92 & 20 & 4.2 & .76 \\
\hline Band Director & $45 \quad 4.28$ & .79 & $40 \quad 3.55$ & .99 & 31 & 3.39 & 1.17 & 17 & 3.53 & 1.01 \\
\hline \multirow[b]{2}{*}{ Group } & \multicolumn{2}{|c|}{ Performing } & \multicolumn{2}{|c|}{$\begin{array}{c}\text { Variety of } \\
\text { Sounds }\end{array}$} & \multicolumn{3}{|c|}{$\begin{array}{c}\text { Career } \\
\text { Opportunities }\end{array}$} & & & \\
\hline & $n$ Mean & $\mathrm{SD}$ & $n \quad$ Mean & $\mathrm{SD}$ & $n$ & Mean & $\mathrm{SD}$ & & & \\
\hline Administrator & 204.31 & .67 & 13 & .77 & 7 & 4.26 & .41 & & & \\
\hline Band Director & 174.47 & .87 & $14 \quad 3.75$ & .96 & 3 & 3.53 & .57 & & & \\
\hline
\end{tabular}

Some interesting trends in the administrators' responses follow.

- Of 193 administrator responses ${ }^{12}$, there was one rating of "disagree" and 12 instances of an "unsure" rating; no "strongly disagrees" were recorded (Table 8).

- Of the 193 administrator ratings, 68 were a rating of "strongly agree" and 86 were a rating of "agree."

- The Creating and Composing theme had the most "disagree" and "unsure" ratings.

- High school administrators (7 respondents) were, generally, slightly more positive in their responses than their middle school counterparts (13 respondents).

- Describing Music was rated higher than Performing.

${ }^{12}$ The total of 193 administrator responses was derived by multiplying the number of middle school respondents (13) by the total number of Likert items for middle school (10) and then adding the number of high school respondents (7) multiplied by the number of Likert items for high school (9). $130+63=193$. 
Table 6

Content Themes for Analysis of Aggregate Administrator and Band Director Data

\begin{tabular}{|c|c|c|c|}
\hline Content Theme & $\begin{array}{c}\text { KY CCA 4.1 } \\
\text { Corresponding Middle School Standards }\end{array}$ & $\begin{array}{l}\text { KY CCA } 4.1 \\
\text { Corresponding High School Standards }\end{array}$ & $\begin{array}{l}\text { Survey } \\
\text { Question }\end{array}$ \\
\hline \multirow[t]{4}{*}{ Describing Music } & $\begin{array}{l}\text { AH-06-1.1.1 Students will identify and describe the use } \\
\text { of elements in a variety of music. }\end{array}$ & - & 11 \\
\hline & $\begin{array}{l}\text { AH-07-1.1.1 Students will analyze the use of elements in } \\
\text { a variety of music. }\end{array}$ & - & 12 \\
\hline & $\begin{array}{l}\text { AH-08-1.1.1 Students will compare and evaluate the use } \\
\text { of elements in a variety of music. }\end{array}$ & & 13 \\
\hline & - & $\begin{array}{l}\text { AH-HS-1.1.1 Students will analyze or evaluate the use } \\
\text { of elements of music in musical compositions. }\end{array}$ & 21 \\
\hline \multirow[t]{6}{*}{ Humanities } & $\begin{array}{l}\text { AH-06/07/08-2.1.1 Students will analyze or explain how } \\
\text { diverse cultures and time periods are reflected in music. }\end{array}$ & - & 14 \\
\hline & $\begin{array}{l}\text { AH-06/07/08-3.1.1 Students will identify or explain how } \\
\text { music fulfills a variety of purposes. }\end{array}$ & & 15 \\
\hline & 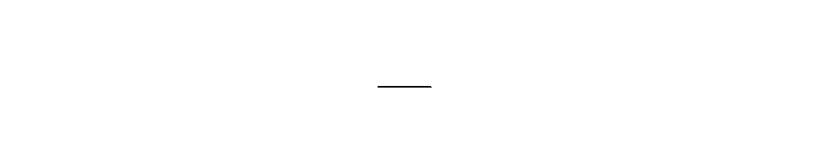 & $\begin{array}{l}\text { AH-HS-2.1.1 Students will analyze or evaluate how } \\
\text { factors such as time, place, and ideas are reflected in } \\
\text { music. }\end{array}$ & 22 \\
\hline & - & $\begin{array}{l}\text { AH-HS-3.1.1 Students will explain how music fulfills a } \\
\text { variety of purposes. }\end{array}$ & 24 \\
\hline & - & $\begin{array}{l}\text { AH-HS-5.5.1 Students will compare one art form (e.g. } \\
\text { music) to another (e.g. visual arts) from the same stylistic } \\
\text { period in another arts discipline (e.g., Impressionism: } \\
\text { Monet to Debussy). }\end{array}$ & 29 \\
\hline & - & $\begin{array}{l}\text { AH-HS-5.5.2 Students will analyze and/or explain how } \\
\text { ideas and emotions expressed in one art form(e.g. } \\
\text { theatre) are similar or different to ideas and emotions } \\
\text { expressed in another art form (e.g. dance). }\end{array}$ & 30 \\
\hline
\end{tabular}


Table 6 (continued)

Content Themes for Analysis of Aggregate Administrator and Band Director Data

\begin{tabular}{|c|c|c|c|}
\hline Content Theme & $\begin{array}{c}\text { KYCCA 4.1 } \\
\text { Corres ponding Middle School Standards }\end{array}$ & $\begin{array}{c}\text { KY CCA 4.1 } \\
\text { Corresponding High School Standards }\end{array}$ & $\begin{array}{l}\text { Survey } \\
\text { Question }\end{array}$ \\
\hline \multirow[t]{2}{*}{ Create and Compose } & $\begin{array}{l}\text { AH-06/07/08-4.1.1 Students will create and notate in } \\
\text { similar style answers to musical phrases. }\end{array}$ & - & 16 \\
\hline & $\begin{array}{l}\text { AH-06/07/08-4.1.3 Students will compose and notate } \\
\text { short pieces of music demonstrating unity/variety, }\end{array}$ & $\underline{-}$ & 18 \\
\hline
\end{tabular}

tension/release, and balance.

AH-HS-4.1.1 Students will create and notate music.

Improvising

AH-06/07/08-4.1.2 Students will improvise variations on given melodies.

Performing

AH-06/07/08-4.1.5 Students will sing or play alone and sustain own part in an ensemble, a given piece of music with increasingly complex melodies and rhythmic patterns in treble and bass clef (with practice).

AH-06/07/08-4.1.4 Students will use a variety of sound

\section{Career Opportunities} instruments, alone or with others, by reading basic music notation (with practice).

AH-HS-4.1.2 Students will improvise rhythmic and/or melodic embellishments and variations on given melodies. sources to create and perform music.

AH-HS-4.1.4 Students will identify skills and training for a variety of careers related to music. 
Trends in the band directors' responses follow next.

- There were 167 total band director responses; ${ }^{13}$ weighted even more heavily toward middle school directors - 14 middle school respondents and 3 high school respondents.

- There were fewer "unsure" ( 2 responses) than administrators but more "strongly disagree" (3 responses, all middle school directors) and "disagree" (19 responses) ratings among band directors (Table 8).

- Additionally, there were 46 ratings of "strongly agree" and 68 ratings of "agree" by band directors.

- Again, the Creating and Composing theme had the most negative ratings-2 "strongly disagree" and 6 "disagree" ratings.

- High school band directors were generally less positive than their middle school counterparts.

- Performing was rated the highest by band directors - the only content theme that band directors rated higher than administrators-and Describing Music was rated second highest.

${ }^{13}$ The total number of band director responses was calculated in the same manner as the total number of administrator responses. $14 * 10+3 * 9=167$. 
Table 8

Composite Likert-Scale Ratings Given by Administrators and Band Directors on All 19 Items

\begin{tabular}{|c|c|c|c|c|c|c|}
\hline & $\begin{array}{l}\text { Strongly } \\
\text { disagree }\end{array}$ & Disagree & Neutral & Agree & $\begin{array}{c}\text { Strongly } \\
\text { agree } \\
\end{array}$ & Unsure \\
\hline Group & $n \quad(\%)$ & $(\%)$ & $(\%)$ & $(\%)$ & $(\%)$ & $n \quad(\%)$ \\
\hline Administrator $(n=193)$ & $0 \quad(0)$ & $1(0.5)$ & $26(13.5)$ & $86(44.6)$ & $68(35.2)$ & $12(6.2)$ \\
\hline Band Director $(n=167)$ & $3(1.8)$ & $19(11.4)$ & $29(17.4)$ & $67(40.1)$ & $47(28.1)$ & $2(1.2)$ \\
\hline
\end{tabular}

Note. Middle school administrators and band directors provided responses to 10 Likert-scale items and high school administrators and band directors responded to 9 Likert-scale items. When multiplied by the number of respondents in each group, the related $n$ values are derived.

Administrators generally believe that band directors are doing a good job of implementing all of the standards in rehearsals and the band program in general. Band directors believe that they are doing a good job of implementing all of the standards in their band programs as well. However, both administrators and band directors believe that the standards in the Describing Music and Performing content themes are the most successfully implemented of the standards while the Creating and Composing and Improvising were the least successfully implemented standards. The overwhelmingly positive natures of the results to this component of the study are similar to the results obtained by Abril and Gault $(2006,2008)$. 


\section{RESEARCH QUESTION 2}

How do administrators observe and assess whether or not their band program is meeting the standards set forth in KY CCA 4.1?

To analyze the data from the open response portion of the study, the responses of administrators were matched into the same content themes as the Likert items were (see Table 6). After the researcher matched the responses to the corresponding content themes, they were coded into themes based on the responses offered. Some responses were coded into multiple themes because they mention multiple ways of assessing a specific standard, and therefore the number of responses coded may or may not add up to the total number of responses collected. There were a total of 100 responses to the standards evaluated by middle and high school administrators. This yields an average of 10 responses per standard or answers from roughly $50 \%$ of respondents.

Generally speaking, the administrators' most common way of assessing the implementation of the content standards was through observations and walk-throughs. ${ }^{14}$ Other less mentioned means of verifying the implantation of standards include lesson plan reviews and the newly instituted Program Review process for the Arts and Humanities (Table 9).

${ }^{14}$ A walk-through is a means of briefly assessing a teacher's adherence to school or district standards and policies for instruction. Similar to a formal observation, a rubric or checklist is used to assess the teacher's instruction. However, they are less formal, sometimes unannounced, and can be as brief as a few minutes in length. Walk-throughs can be viewed as a snap-shot of a teacher's performance. 
Table 9

How Administrators Reported Observing Standard

Implmentation in the Band Program

\begin{tabular}{lcc}
\hline Theme & Responses & $\%$ \\
\hline Specifically mention observation & 18 & $18 \%$ \\
Specifically mention lesson plans & 3 & $3 \%$ \\
Specifically mention program review & 6 & $6 \%$ \\
Specifically mention "Not observed" & 3 & $3 \%$ \\
\hline
\end{tabular}

There were, however a number of administrators that did not specifically mention observation, lesson plans, or Program Reviews but did describe an activity that presumably had been observed by the administrator in some manner. Table 10 shows the number of times an administrator mentioned performance, a classroom activity, or a collaborative effort in their evaluation of a standard's implementation. There were also a large number of responses that simply listed a specific course or courses (e.g., "band" or "band, choir, arts and humanities"). Table 11 shows the frequency of these types of responses as well as the number of responses acquired that were inappropriate for the question asked (i.e., an answer that simply referred to "arts and humanities" when respondents were asked to evaluate the standard with regards to the band program only). Again, there may be some overlap between the numbers listed in Tables 9, 10, and 11 due to the coding of some responses into multiple themes, and therefore percentages will not add up to $100 \%$. 
Table 10

Activities Observed by Administrators During the

Implementation of Standards in the Band Program

\begin{tabular}{|c|c|c|}
\hline Theme & Responses & $\%$ \\
\hline Specifically mention performance & 29 & $29 \%$ \\
\hline Specifically mention a class activity $^{a}$ & 16 & $16 \%$ \\
\hline $\begin{array}{l}\text { Specifically mention sollaboration } \\
\text { between content areas }\end{array}$ & 2 & $2 \%$ \\
\hline
\end{tabular}

Table 11

Administrator Responses that Listed a Single Course or Courses Where a Standard Has Been Observed

\begin{tabular}{lcc}
\hline Theme & Responses & $(\%)$ \\
\hline Specifically mention a course(s) & 27 & $27 \%$ \\
& & \\
$\begin{array}{l}\text { Answers that were inappropriate } \\
\text { the for }\end{array}$ & 17 & $17 \%$
\end{tabular}

${ }^{a}$ Inappropriate answers include those that listed a course or activity not obsevred in the band program, e.g., Arts \& Humanities classes or general music classes.

A sampling of the responses shows that there are many instances in which administrators are very aware of standards implementation and in other cases ignorant of the standards all together. With regards to the Describing Music content theme, one administrator wrote

"Students on a regular basis define music element terms, provide examples, or perform the term." 
Another one stated,

"Students sing and play a variety of instruments and our music classes have keyboard labs."

One answer clearly demonstrates an understanding of the standard asking students to (essentially) "describe the use of musical elements in music." The other one does not show the same level of understanding. Most answers however, fell in between these two extremes; either specifying a manner in which each standard was observed or an activity that was completed to meet the standard. The following are highlights of the answers from each of the other content themes. ${ }^{15}$

About the Humanities standards, administrators wrote:

"Have not observed"

"Types of music being played or sung is identified and explained both by band and music/choir"

"Students attend concerts, play musicals, and perform for their peers"

About the Creating and Composing standards some wrote:

"Our teachers have students create their own music. They is ten to [perform for] each other and critique it"

"Our musicians compose and critique their music"

"Student compositions are encouraged through the gifted and talented area"

"One student wrote the pep band's favorite pep song"

\footnotetext{
${ }^{15}$ For the sake of content, I will not quote instances in which a response simply listed "classroom observations," "band class," or is vague enough to require listing the question to understand the answer written.
} 
Administrators shared this about Improvising:

"Not observed"

"Teacher had students improvise music using elements they were learning"

In regards to Performing:

"Individual performances"

"Ensembles for KMEA"

"Students participate in several events. Musical performances, solo \& ensembles, honors band. All county and district band."

"Concerts classroom observations rehearsals camp"

In the middle school, for the Variety of Sounds theme, administrators wrote,

"All students are given the opportunity to play a variety of instruments"

"Not sure what you mean by sound sources? If you mean, variety of instrumentation; absolutely."

And finally, one administrator said that "Seniors do senior projects and some are on music as a career," in reference to the high school standard relating to music as a Career Opportunity. 


\section{RESEARCH QUESTION 3}

How do band directors implement the content standards specified in KY CCA 4.1 within the rehearsal process; what techniques have they discovered that work?

The band directors offered a slightly greater number of responses to the open response questions accompanying the Likert items -11 responses on average (111 total), representing roughly $65 \%$ of the band directors who responded to the survey. The responses were coded within the same content themes (Table 6) used to analyze the open response data for the administrators and the Likert scale items. Like the administrator responses, some responses were coded into multiple themes because they specifically mention more than one technique or setting in which a standard is implemented by the band director. Therefore, the numbers represented in Table 12 may or may not add up to the total number of responses gathered from the band directors.

Table 12

How Band Directors Reported Implementing the Standards in the Band Program

\begin{tabular}{lcc}
\hline Theme & Responses (\%) \\
\hline Specifically mention rehearsal or performance & 51 & $45.9 \%$ \\
Specifically mention a class activity & 30 & $27 \%$ \\
Specifically mention discussion & 20 & $18 \%$ \\
$\begin{array}{l}\text { Specifically mention a course(s) } \\
\text { Specifically mention a standard is not, } \\
\text { or rarely implemented }\end{array}$ & 7 & $6.3 \%$ \\
\hline
\end{tabular}

Table 12 displays the number of band director responses that specifically mention implementing content standards in rehearsal or performance, homework or other written 
work, those that utilize discussion as means of communicating the content for a standard, as well as those who said they "rarely" or do not implement a standard, and finally, the band directors that only listed a specific class in which content was taught.

Band directors, in general, appeared to be able to easily integrate most content standards into the rehearsal setting, either through performance, discussion, written work, or a combination of the three. Some directors provided an in-depth look at strategies they use to implement the Describing Music standards into the rehearsal. For instance, one middle school director shared his strategy:

We use the elements in all the music we play and it is drawn to their attention in every class period. We start in the $6^{\text {th }}$ grade and study the musical elements as an on going process. We identify and write what they are in every class as part of the workshop process we do in each piece of music we study. Students are to identify and annotate on the music every musical element and concept they can identify before we play a note. We do this up front and allow the students to be responsible for their learning of the parts.

A high school director says,

Students are trained over time to recognize formal structures within their musical parts/others parts (motives, phrases, etc.) as well as utilize the elements of tempo, meter, dynamics, and expressive qualities. This happens in full ensemble rehearsals, sectional work, and individual lessons.

A middle school director combines Describing Music with the Creating and Composing and Performing Standards:

Students create and perform self composed music in front of their peers. Students watching the performances use a rubric to score the group based on their use of various elements of music. Students then choose two groups to compare, and make an argument for which group's performance was the best. 
These three examples show how some directors strive to directly integrate some of the standards into the rehearsal process instead of having a separate discussion about the content. In general, the band directors were much more specific about how the standards are implemented than the administrators, which is to be expected. What follows are snapshots of the responses for the other content themes. ${ }^{16}$

With consideration to the Humanities in the band rehearsal, directors shared the following:

"I don't know that we "explain" it [the purposes of music], but we sure demonstrate it!"

"Perform pieces of a variety of cultures - Latin, African, Asian, Indian, etc. Use of authentic instruments when available."

Others incorporate discussion and writing into the rehearsal process.

The students must be able to identify the purposes after listening to examples and also after concerts and assemblies. We discuss the difference in Secular music as opposed to Sacred Music. They know the difference between the lets say, the "Star Spangled Banner" and Modern music. We have them describe in writing what the differences are and how each would be used after discussing it in length.

Some shared an admitted lack of instruction on the Humanities in music:

"Different cultures are explored but not thoroughly explored."

"Rarely completed unless studying a piece that relates."

${ }^{16}$ Again, there were some directors who provided valid answers to the questions but did not provide a specific strategy or technique questions - these answers will be excluded from this discussion for the sake of disseminating the most valuable content to the reader. 
Creating and Composing in the band is described as well.

"We have an 'in-house' student composition contest for the $7^{\text {th }}$ grade."

"Older students do a composition project at the end of the year."

"Students just completed a composition homework assignment that had to reflect a specific mood."

I don't teach composition because I don't have time to teach it plus teach them how to play their instruments. Their book allows them to do some very simple composition and that's where I leave it unless I have a student that is interested in composition and then I will work with them one on one.

Two high school directors simply said that Improvisation was taught in "Jazz Ensemble."

Middle school directors shared the following about Improvisation:

"I don't teach improvisation because I don't have time to teach it correctly."

"Improv is taught when it relates to a piece. Last year I did it in $6^{\text {th }}$ grade."

"We spend time with jazz music in February, and we discuss the process of improvisation. We also 'improvise' on the $\mathrm{Bb}$ major scale using various rhythms to guide choice. However, we do not specifically create 'variations on a melody.""

About the Performance standard, band directors said the following, in addition to those that simply mentioned "Daily activities" or "Band in all three grades:"

"Constantly-every day. When I ask to hear the baritone section, they are sustaining their own part separately, then in the context of the ensemble."

"All students are required to participate in a solo or ensemble. Students also have 2-4 smart music tests every term."

"They do this using only their own clef. Everyday." 
With regards to the singing component of the Performance standard:

"Minimal singing in band class, but what we do is very necessary for developing quality musicianship."

"Students sing parts alone using solfege, they are also able to play parts alone or in an ensemble.

One director outlined the multitude of performance opportunities for their students.

" 4 concerts for Concert Bands and Guitar Ensembles (one each 9 week grading period), Solo and Ensemble/ Festival Performances, Young Composers Recital, Pit Orchestra, Pep Band, Marching Band, Jazz Band."

Finally, middle school directors responded to the Variety of Sounds theme saying,

"Often I select music that requires students to use their instruments in a variety of ways."

"We are using a combination of different timbres (different instruments in the band). This is perhaps most applicable to percussionists, who must use different sources each day."

"I call it the Sound Source Project. We talk about aerophones and cordophones etc.. and then ask them to create their own instrument."

"I try to expose them to as much as I can when the situation allows it. They know the difference between acoustical and synthesized music. We just do not get the opportunity to use a keyboard that often."

And, a high school band director shared the following about their students' exposure to Career Opportunities in music as, "Visitors representing music education, music therapy and music performance occasionally present to students during class." 


\section{CHAPTER 5}

\section{DISCUSSION}

The data resulting from this study yields much useful information to secondary school band directors. First it provides a means to frame any gaps between what administrators are seeing and band directors are doing with respect to Kentucky's CCA 4.1 in music. Second, it can help identify what band directors are doing that is working or readily observable by administrators. Finally, the data confirms that there is possibly a need to think about whether or not band directors need to address every standard within the scope of the band class and rehearsals.

As mentioned earlier, the positive responses of the administrators and band directors to the Likert scale items is to be expected based on the results of the studies by Abril and Gault $(2006,2008)$. The band directors were less positive than the administrators and that indicates that they are indeed more discriminating in their ratings of the content standards. The larger quantity of "strongly disagree" and "disagree" ratings coupled with a smaller percentage of "agree" and "strongly agree" ratings from band directors appear to bear this out (Table 8). This also may indicate a gap in what administrators are observing and what they are allowing for the "benefit of the doubt" in their assessments. The larger number of "unsure" ratings given by the administrators to the content standards lends credence to this theory. 
This trend can also be witnessed in the answers to the open response questions. When asked to provide an example of how a standard was observed (administrators) or implemented (band directors), administrators provided answers that were less easily codified than the band directors. This is perhaps because band directors are able to talk in more specific terms about the activities in the band rehearsal than administrators are. Administrators can sometimes be deficient in the vocabulary and processes involved in the music making process and cannot talk in such specific terms about what they are seeing. They may also only receive exposure to these specific processes in brief and infrequent intervals, hindering their ability to reasonably assess whether or not a standard is being taught. They therefore may give the band director the "benefit of the doubt" that certain standards are being met, when in fact the band directors may not agree.

A few interesting trends in the observations offered by the administrators are worth discussing. First, in the Describing Music theme, only $25 \%$ of responses included a specific classroom activity. Most of the rest of the responses simply listed how or when it had been observed — this should not be construed as useless information however, as finding out that this is a standard administrators may observe through observations or lesson plans is important. It does however, lend some validity to the previous discussion that administrators may be deficient in understandings required to accurately validate their assessment of content standards.

Second, the content themes with the lowest means, Improvise and Create and Compose, had fewer responses to the open response questions, on average, than the other themes and within these responses had even fewer specific activities described. Even with a lower rating from administrators, a fair bit of disagreement still exists between 
administrators and band directors within the Create and Compose content theme. More band directors, not only rated this standard lower than others, but some openly admitted that they do not have time to teach about composition or they assign it as out of class homework or projects. These results could have been expected based on the findings of Abril and Gault (2006, 2008) and Bell (2003).

If this standard is implemented as homework, administrators may or may not know that it is taking place. Additionally, if one takes into consideration that administrators may be giving the directors the "benefit of the doubt" on this standard that would potentially explain why administrators provided fewer examples of how this standard was observed when prompted - they cannot write about what they do not know of or see. A similar argument could be made with respect to the Improvise standards.

Some similarities exist between administrators and band directors based on the open responses they provided for a few standards. For instance, Creating and Composing was seen by both groups as an "enrichment" activity or something to be completed as a project or homework outside of the scope of a normal rehearsal. The Describing Music theme tended to be viewed as content for discussion; however some directors try to actively integrate the musical elements into the rehearsal process. The Humanities were also viewed as something for discussion, though admittedly integrating the humanities into the band rehearsal is not as easy as is integrating the musical elements. Improvising was viewed as something generally for jazz band by both groups, though some directors tried to implement the standard in the regular band rehearsal. 
Finally, the Performing standards were perceived highly by both groups. This is not surprising since it is what band is really all about—experiencing the content standards for music through performance. Positively, a few administrators recognized that there are multiple performance opportunities within school and out of school for students in band-including KMEA Concert Festival and Solo and Ensemble, All-County and AllDistrict bands - in addition to school performances. This means that there is high visibility within the community for the band programs and this is an important component of advocacy, especially at the school level.

The final point of discussion is based around the number of responses that indicated that some standards were, more often than not, indicated to have been implemented in courses outside of band. Many of these answers were considered "inappropriate for the question asked" when coded due to the fact that the question asked about how a standard was implemented in band only. These answers frequently mentioned arts and humanities classes, general music, choir, and, even in a few instances, collaboration between the social studies department and social studies curriculum. While these answers are not particularly relevant to the study at hand, they are important in helping to define a concept for a music program or arts and humanities program as a whole.

Fallis (1994) suggests that the ideal music program would consist of a core of classes separate from large ensembles in which the student body could become versed in musical content. He proposes that ensembles should become more of an enrichment program focusing on performance of the music standards. In this instance, band directors would not necessarily need to meet all standards every day or even at all, depending on 
the nature of the course and content. Hoffer (2009) and MENC (1994) further state that not all courses need contain equal portions of each standard, but that all courses should incorporate at least a small amount of each, as relevant to the inherent nature of the course.

The responses of administrators and band directors in this study and the conditions on instruction of the music standards proposed by Fallis, Hoffer, and MENC help to further validate the new Kentucky Program Review process as an authentic and meaningful way to assess the arts programs in Kentucky schools. Since the band programs surveyed in this study only serve, on average, roughly $17 \%$ of their respective school population, the arguments for a rethinking of the curriculum in music and band may need to be postponed; Many students in band only receive music instruction through band and, therefore still need to be exposed to all of the content and standards required by Kentucky's CCA 4.1. Maybe band and other performance courses at the secondary school level need to incorporate as many standards into the curriculum as possible. However, this is a discussion to be had beyond the scope of this paper.

\section{LIMITATIONS AND PROBLEMS OF THIS STUDY}

The first problem faced by this study is the low response rate from both administrators and band directors. One reason for this may be the time of year. Administrators are finishing the school year and approaching the standardized testing windows imposed by the state. Band directors, while busy all year round, are often preoccupied with preparations for KMEA Concert Festival in the spring. Extra 
rehearsals, sectionals, and lessons in preparation for Festival are enough to keep many directors busy before accounting for other administrative duties that go along with being a band director. Taking all of this into consideration, it is not surprising that so few administrators and band directors completed the survey. Combined with a sample size that limited the number of potential participants in the state, the low response rate was compounded.

There are also a number of biases that could be present in the results of this study. First, there is a potential bias in the responses as band directors who are busier than others may not have completed the survey. Furthermore, older populations may be more averse to completing an online survey than younger populations. A final bias may be found in administrators or directors that believed, correctly or not, that they may or may not be qualified or competent enough to discuss the content matter of the current study and therefore did not participate.

Due to the low response rate, the aggregate data for both the administrator and band director samples was used. Results may not accurately reflect what middle school administrators and band directors are thinking and doing, and likewise, the data provided by respondents at the high school level may not be accurately portrayed either. However, the results do provide a general picture of how and what administrators and band directors think about the implementation of KY CCA 4.1 in music.

Also, the low response rate does not allow for a comparison between administrators and band directors at the same schools. A larger response rate may have allowed for an opportunity to pair some data from administrators and band directors and 
make direct comparisons between them. While it would have helped to offset the low response rate, due to time constraints the researcher was unable to develop material and contact participants who were willing to participate in follow-up questions that would have added another layer of data to the results.

\section{RECOMMENDATIONS FOR FUTURE STUDY}

For future study, it would not be unreasonable to survey all of the secondary school administrators and band directors in the state of Kentucky. This may seem like a rather daunting task, but band director names and emails are readily accessible through the Kentucky Music Educators Association's website. While locating the names of the administrators at secondary schools in Kentucky would seem impossible, it did not take more than a few hours to locate the names of the secondary school administrators in 31 counties, or a little more than $25 \%$ of all the counties in Kentucky, via school web pages. The larger sample size would allow for more direct comparisons between middle school administrators and band directors and high school administrators and band directors.

More guidance on the open response questions may help derive more meaningful answers than "observations," or "band class" which, while they describe where a standard was observed, do little to go beyond the surface. Along this same vein, more of a true qualitative study may provide even more insight into what administrators are observing and what band directors are teaching in the classroom. This could even be done by matching band directors and their administrators to provide for direct relationships to be made. Additionally, a similar study could examine how administrators specifically assess 
music instruction in their schools. Based on the number of administrators and band directors in the current study that indicated they were willing to participate in possible follow-up questions, finding participants may make a qualitative study a viable option in the future. 


\section{REFERENCES}

Abril, C. R. \& Gault, B. M. (2005). Elementary educators' perceptions of elementary general music instructional goals. Bulletin of the Council for Research in Music Education, 164, 61-69.

Abril, C. R. \& Gault, B. M. (2006). The state of music in the elementary school: The principal's perspective. Journal of Research in Music Education, 54(1), 6-20.

Abril, C. R. \& Gault, B. M. (2008). The state of music in secondary schools: The principal's perspective. Journal of Research in Music Education, 56(1), 68-81.

American School Band Directors Association. (1997). The new ASBDA curriculum guide. Van Nuys, CA: Alfred.

Bell, C. L. (2003). Beginning the dialogue: Teachers respond to the National Standards in music. Bulletin of the Council for Research in Music Education, 156, 31-42.

Bresler, L. (1993). Music in a double-bind: Instruction by non-specialists in elementary schools. Bulletin of the Council for Research in Music Education, 115, 1-13.

Byo, S. J. (1999). Classroom teachers' and music specialists' perceived ability to implement the national standards for music education. Journal of Research in Music Education, 47(2), 11-123.

Črnčec, R., Wilson, S. J., \& Prior, M. (2006). No evidence for the Mozart effect in children. Music Perception: An Interdisciplinary Journal, 23(4), 305-318. 
Deisler, A. M. (2011). A comparison of common characteristics of successful high school band programs in low socioeconomic schools and high socioeconomic schools (Doctoral dissertation). Retrieved from Proquest. (UMI 3483552)

Demorest, S. M. \& Morrison, S. J. (2000). Does music make you smarter? Music Educators Journal, 87(2), 33-39+58.

Eisner, E. (1958). What is art education for? The High School Journal, 4l(6), 263-267.

Eisner, E. (1967). Educational objectives: Help or hindrance? American Journal of Education, 91(4), 549-560.

Fallis, T.L. (1994). National Standards: What's next. Music Educators Journal, 81(3), $26-28+47$.

Fisher, R. (2008). Debating assessment in music education. Research and Issues in Music Education, 6(1). Retrieved from http://www.stthomas.edu/rimeonline

Fitzpatrick, K. R. (2006). The effect of instrumental music participation and socioeconomic status on Ohio fourth-, sixth-, and ninth- grade Proficiency Test performance. Journal of Research in Music Education, 54(1), 73-84.

Goble, J. S. (2010). What's so important about music education?. New York, NY: Routledge.

Goodstein, R. E. (1987). An investigation in the leadership behaviors and descriptive characteristics of high school band directors in the United States. Journal of Research in Music Education, 35(1), 13-25.

Gordon, M. (1979). Instrumental music instruction as a contingency for increased reading behavior. Journal of Research in Music Education, 27(2), 87-102. 
Goals 2000: Educate America Act. (1994). Public Law 103-227. Retrieved from http://www2.ed.gov/legislation/GOALS2000/TheAct/index.html

Hoffer, C. F. (2009). Introduction to music education (3rd ed.). Long Grove, IL: Waveland Press.

Johnson, C. M. \& Memmott, J. E. (2006). Examination of relationships between participation in school music programs of differing quality and standardized test results. Journal of Research in Music Education, 54(4), 293-307.

Kentucky Department of Education. (2006). Core content for arts and humanities assessment, version 4.1. Retrieved from http://kde.state.ky.us

Kentucky Department of Education. (2009). Senate Bill 1 highlights. Retrieved from http://www.kde.state.ky.us/KDE/Administrative+Resources/Commissioner+of+ Education/Unbridled+Learning/

Kentucky Department of Education. (2011a). KDE program review guide for arts and humanities. Retrieved from http://kde.state.ky.us

Kentucky Department of Education. (2011b). Kentucky Department of Education Program review guide for practical living/career studies, writing, and arts and humanities, Sections 1-3. Retrieved from http://kde.state.ky.us

Kinney, D. W. \& Forsythe, J. L. (2005). The effects of the Arts IMPACT curriculum upon student performance on the Ohio Fourth-Grade Proficiency Test. Bulletin of the Council for Research in Music Education, 164, 35-48.

Kentucky Education Reform Act of 1990, KRS § 476-1-4 (1990). Retrieved from http://libguides.wku.edu/kera

Kentucky Music Educators Association. (2011a). KMEA festival rules. Retrieved from http://www.kmea.org/FESTIVAL/ 
Kentucky Music Educators Association. (2011b). Marching band performance assessment event rules and regulations handbook. Retrieved from http://www.kmea.org/infocenter/

McCoy, C. W. (1991). Grading students in performing groups: A comparison of principals' recommendations with directors' practices. Journal of Research in Music Education, 39(3), 181-190.

MENC-The National Association for Music Education. (1994). The school music program: A new vision. Reston, VA: Music Educators National Conference.

Rauscher, F. H. (1999). Music exposure and the development of spatial intelligence in children. Bulletin of the Council for Research in Music Education, 142, 35-47.

Rauscher, F. H., Shaw, G. L., \& Ky, K. N. (1993). Music and spatial task performance. Nature, $365,611$.

Rauscher, F. H., Shaw, G. L., \& Ky, K. N. (1995). Listening to Mozart enhances spatialtemporal reasoning: Toward a neurophysiological basis. Neuroscience Letters, $185,44-47$.

Reimer, B. (1989). A philosophy of music education (second edition). Englewood Cliffs, NJ: Prentice Hall.

Reimer, B. (1999). Facing the risks of the "Mozart effect." Music Educators Journal, $86(1), 37-43$.

Reimer, B. (2009). Merely listening. In B. Reimer (Ed.), Seeking the significance of music education: Essays and reflections (pp. 221-235). Reston, VA: MENC: The National Association for Music Education. 
Rogers, G. L. (1985). Attitudes of high school band directors and principals toward marching band contests. Journal of Research in Music Education, 33(4), 259267.

Saunders, T. C. \& Baker, D. S. (1991). In-service classroom teachers' perceptions of useful music skills and understandings. Journal of Research in Music Education, $39(3), 248-261$.

Schellenberg, G. E. (2005). Music and cognitive abilities. Current Directions in Psychological Science, 14(6), 317-320.

Steele, K. M., Bass, K. E., \& Crook, M.D. (1999). The mystery of the Mozart effect: Failure to replicate. Psychological Science, 10(4), 366-369.

Tungate, M. (2010). Program reviews a shift from test-centered to program-centered. Kentucky Teacher. Retrieved from http://www.kentuckyteacher.org/features/2010/09

U.S. Department of Education, National Commission on Excellence in Education. (1983). A nation at risk. Retrieved from http://www2.ed.gov/pubs/NatAtRisk/index.html

Vitter, C. L. (2011). An analysis of program leadership through the lens of Louisiana band directors (Doctoral dissertation). Retrieved from Proquest. (UMI 3482454)

Western Kentucky University. (2012). Kentucky Education Reform Act. http://libguides.wku.edu/kera

Zellner, R. M. (2011). A study of the relationship between instrumental music education and critical thinking in 8th- and 11th- grade students (Doctoral dissertation). Retrieved from Proquest. (UMI 3450574) 


\section{APPENDIX A \\ Kentucky Core Content for Assessment 4.1 (CCA 4.1) in Music}

CONTENT STANDARDS FOR MIDDLE SCHOOL MUSIC

AH-06-1.1.1

AH-07-1.1.1

AH-08-1.1.1

AH-06/07/08-2.1.1

AH-06/07/08-3.1.1

AH-06/07/08-4.1.1

AH-06/07/08-4.1.3

AH-06/07/08-4.1.2

AH-06/07/08-4.1.5

AH-06/07/08-4.1.4
Students will identify and describe the use of elements in a variety of music.

Students will analyze the use of elements in a variety of music.

Students will compare and evaluate the use of elements in a variety of music.

Students will analyze or explain how diverse cultures and time periods are reflected in music.

Students will identify or explain how music fulfills a variety of purposes.

Students will create and notate in similar style answers to musical phrases.

Students will compose and notate short pieces of music demonstrating unity/variety, tension/release, and balance.

Students will improvise variations on given melodies.

Students will sing or play alone and sustain own part in an ensemble, a given piece of music with increasingly complex melodies and rhythmic patterns in treble and bass clef (with practice).

Students will use a variety of sound sources to create and perform music. 


\section{CONTENT STANDARDS FOR HIGH SCHOOL MUSIC}

AH-HS-1.1.1

AH-HS-2.1.1

AH-HS-3.1.1

AH-HS-4.1.1

AH-HS-4.1.2

AH-HS-4.1.3

AH-HS-4.1.4

AH-HS-5.5.1

AH-HS-5.5.2
Students will analyze or evaluate the use of elements of music in musical compositions.

Students will analyze or evaluate how factors such as time, place, and ideas are reflected in music.

Students will explain how music fulfills a variety of purposes.

Students will create and notate music.

Students will improvise rhythmic and/or melodic embellishments and variations on given melodies.

Students will sing or perform on instruments, alone or with others, by reading basic music notation (with practice).

Students will identify skills and training for a variety of careers related to music.

Students will compare one art form (e.g. music) to another (e.g. visual arts) from the same stylistic period in another arts discipline (e.g., Impressionism: Monet to Debussy).

Students will analyze and/or explain how ideas and emotions expressed in one art form(e.g. theatre) are similar or different to ideas and emotions expressed in another art form (e.g. dance). 


\section{APPENDIX B \\ Recruiting Letters (Administrator)}

\section{INITIAL EMAIL CONTACT}

Dear Administrator,

My name is David Buchholz and I am a graduate student at the University of Louisville under the supervision of Dr. Robert Amchin, head of the division of Music Education and Therapy. I am completing my thesis this spring. I am requesting your help with my study. My research is seeking to survey secondary school administrator and band director perceptions of their school's band program as it relates to Kentucky Core Content for music. The brief survey will ask about each school's demographics and then ask the administrator or band director to rate the band program's implementation of Kentucky CCA 4.1 in music as well as provide a brief example of how the standards have been observed or implemented by the band director.

If you agree to participate, please follow the accompanying link to access my online survey. No personally identifying information about you or your school is required or recorded. In addition to answering my survey, you will also be invited to participate in possible follow-up contacts beyond the basic questions online. You will be given an opportunity to provide this information at the end of the survey. Please affirm your consent to participate in the study on the first page of the study and answer each question to the best of your ability. The survey should take 5-10 minutes to complete.

[Survey link inserted here]

If you have any questions, comments, or concerns please do not hesitate to contact by email or by phone.

Thank you for taking time out of your busy day to help me with this endeavor.

Sincerely,

David A. Buchholz

Masters Candidate in Music Education

University of Louisville School of Music

Cell:

Email: 


\section{FOLLOW-UP/REMINDER EMAIL}

\section{Dear Administrator,}

If you have not yet completed the survey I emailed to you last week, it is not too late! If you have already completed the survey, please feel free to disregard this letter.

Again, my name is David Buchholz. I am a graduate student in the University of Louisville School of Music and my research is seeking to survey secondary school administrator and band director perceptions of their school's band program as it relates to Kentucky Core Content for music. The brief survey will ask about each school's demographics and then ask the administrator or band director to rate the band program's implementation of Kentucky CCA 4.1 in music as well as provide a brief example of how the standards have been observed or implemented by the band director.

If you agree to participate, please follow the accompanying link to access my online survey. No personally identifying information about you or your school is required or recorded. In addition to answering my survey, you will also be invited to participate in possible follow-up contacts beyond the basic questions online. You will be given an opportunity to provide this information at the end of the survey. Please affirm your consent to participate in the study on the first page of the study and answer each question to the best of your ability. The survey should take 5-10 minutes to complete.

[Study link inserted here]

If you have any questions, comments, or concerns please do not hesitate to contact me by email or by phone.

Thank you for taking time out of your busy day to help me with this endeavor.

Sincerely,

David A. Buchholz

Masters Candidate in Music Education

University of Louisville School of Music

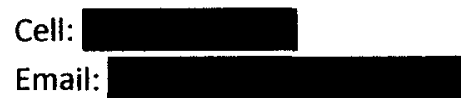




\begin{abstract}
APPENDIX C
Recruiting Letters (Band Director)

INITIAL EMAIL CONTACT

Dear fellow Band Director,

My name is David Buchholz and I am a band director and current graduate student at the University of Louisville under the supervision of Dr. Robert Amchin, head of the division of Music Education and Therapy. I am completing my thesis this spring. I am requesting your help with my study. My research is seeking to survey secondary school administrator and band director perceptions of their school's band program as it relates to Kentucky Core Content for music. The brief survey will ask about each school's demographics and then ask the administrator or band director to rate the band program's implementation the Kentucky CCA 4.1 in music as well as provide a brief example of how the standards have been observed or implemented by the band director.

If you agree to participate, please follow the accompanying link to access my online survey. No personally identifying information about you or your school is required or recorded. In addition to answering my survey, you will also be invited to participate in possible follow-up contacts beyond the basic questions online. You will be given an opportunity to provide this information at the end of the survey. Please affirm your consent to participate in the study on the first page of the study and answer each question to the best of your ability. The survey should take 5-10 minutes to complete.
\end{abstract}

[Survey link inserted here]

If you have any questions, comments, or concerns please do not hesitate to contact by email or by phone.

Thank you for taking time out of your busy day to help me with this endeavor.

Sincerely,

David A. Buchholz

Masters Candidate in Music Education

University of Louisville School of Music

Cell:

Email: 


\section{FOLLOW-UP/REMINDER EMAIL}

Dear fellow Band Director,

If you have not yet completed the survey I emailed to you last week, it is not too late! If you have already completed the survey, please feel free to disregard this letter.

Again, my name is David Buchholz. I am a graduate student in the University of Louisville School of Music and my research is seeking to survey secondary school administrator and band director perceptions of their school's band program as it relates to Kentucky Core Content for music. The brief survey will ask about each school's demographics and then ask the administrator or band director to rate the band program's implementation the Kentucky CCA 4.1 in music as well as provide a brief example of how the standards have been observed or implemented by the band director.

If you agree to participate, please follow the accompanying link to access my online survey. No personally identifying information about you or your school is required or recorded. In addition to answering my survey, you will also be invited to participate in possible follow-up contacts beyond the basic questions online. You will be given an opportunity to provide this information at the end of the survey. Please affirm your consent to participate in the study on the first page of the study and answer each question to the best of your ability. The survey should take 5-10 minutes to complete.

[Survey link inserted here]

If you have any questions, comments, or concerns please do not hesitate to contact me by email or by phone.

Thank you for taking time out of your busy day to help me with this endeavor.

Sincerely,

David A. Buchholz

Masters Candidate in Music Education

University of Louisville School of Music

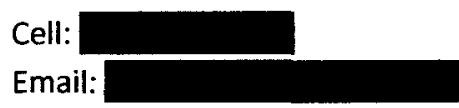




\section{APPENDIX D \\ Survey (Administrator) \\ Administrator and Band Director Perceptions of the Implementation of KY Core Content for Assessment in Music (Administrator)}

\section{CONSENT}

You have been invited to participate in a research study being conducted by David Buchholz, student at the University of Louisville, and Dr. Robert Amchin, Faculty Advisor. You are one of many other public secondary school administrators and band directors from the Louisville Metropolitan region and northwest-central Kentucky that have been invited to participate.

The purpose of this study is to understand administrator and band director perceptions of their school band program's implementation of the state of Kentucky's Core Content for Assessment 4.1 in music.

The following survey will ask you for demographic information about your school and then ask you to rate your level of agreement with ten (10) statements relating to CCA 4.1 for music and complete an equal number of short answer open response-type questions. The entire survey should take no more than 5-10 minutes to complete.

There are no foreseeable risks in participation, although there may be unforeseen risks.

The possible benefits of this study include a greater understanding among music educators of how their classroom instruction with regards to CCA 4.1 is perceived by band directors and their administrators. This information and other information collected may not benefit you directly, but it may be helpful to others.

You will not be compensated for your time, inconvenience, or expenses for your participation in this study.

Total privacy cannot be guaranteed. Your privacy will be protected by the extent permitted by law. If the results from this study are published, your name will not be made public. While unlikely, the following may look at the study records:

The University of Louisville institutional Review Board, Human Subjects Protection Program Office, and Privacy Office, Office for Human Research Protections (OHRP), Office of Civil Rights.

\section{All data collected in this study will be kept in a password protected computer.}

Taking part in this study is voluntary. You may choose to not take part at all. If you decide to be in this study you may stop taking part at any time. If you decide not to be in this study or if you stop taking part at any time, you will not lose any benefits for which you may qualify. 
You will be told about any changes that may affect your decision to continue in the study.

If you have any concerns or complaints about the study or study staff, you have three options.

You may contact David Buchholz (216) 401-7554 or Dr. Robert Amchin, Faculty Advisor (502) $852-0536$

If you have any questions about your rights as a study subject, questions, concerns or complaints, you may call the Human Subjects Protection Program Office (HSPPO) (502) 852-

5188. You may discuss any questions about your rights as a subject, in secret, with a member of the Institutional Review Board (IRB) or the HSPPO staff. The IRB is an independent committee composed of members of the University community, staff of the institutions, as well as lay members of the community not concerned with these institutions.

The IRB has reviewed this study.

If you want to speak to a person outside of the University, you may call 1-877-852-1167. You will be given a chance to talk about any questions, concerns or complaints in secret. This is a 24hour hot line answered by people who do not work at the University of Louisville.

By clicking "Agree" below you are agreeing to take part in the study. By agreeing you are not giving up any legal rights. You may print a copy of this document to keep for your records by clicking here.

Do you agree to participate in the study, "Administrator and Band Director Perceptions of the Implementation of KY Core Content for Assessment in Music," as administered by David Buchholz, student in the University of Louisville School of Music?

YES

NO

\section{SCHOOL DEMOGRAPHICS}

Please answer the following demographic questions about your school.

1. Does your school offer music instruction?

YES

NO

2. Is band one of the instrumental music courses that is offered?

YES

NO 
3. Does your school require any form of music instruction, such as Band, Choir, Orchestra, and Arts and Humanities classes?

YES

NO

4. Who dictates the requirements for music instruction?

School Board

Site Based Decision Making council

school administration

music teacher

combination of any of the above

other

5. What grade levels does your school serve?

6-8

$9-12$

$\mathrm{P}-12$

other

If you selected "other" for Question 5, please specify the grade levels served by your school?

6. How many students attend your school (approximately)?

7. How would you describe you school's location?

urban

suburban

rural 
8. Approximately what percentage of students at your school receive free or reduced price lunches?

less than $10 \%$

$11-25 \%$

$26-50 \%$

$51-75 \%$

more than $75 \%$

9. What music courses does your school offer (select all that apply)?

general music

general music within an Arts \& humanities course

band

orchestra

choir/chorus

percussion ensemble

jazz band

piano/keyboard

guitar

music theory or history

other

If you selected "other" for Question 9, please specify what other courses you offer.

10. Please specify the number of music specialists working at your school (full-time equivalent).

How many teach band (FTE)? 


\section{PLEASE SELECT A GRADE LEVEL FOR THE SURVEY}

If your school is a P-12 campus, please indicate the grade levels you are most comfortable assessing when talking about music instruction in your school.

$6-8$

9-12

\section{PLEASE SELECT A GRADE LEVEL FOR THE SURVEY}

If you answered "other" to Question 5, please select the option below that most closely aligns with the grade levels served by your school.

6-8

9-12

\section{MIDDLE SCHOOL (GRADES 6-8) SURVEY}

This study is seeking to survey administrator perceptions of KY Core Content for Assessment (CCA 4.1) in Music as implemented in band rehearsals or concerts by your band director.

Please indicate your overall agreement with the following statements, as outlined in CCA 4.1.

If possible, please provide an example of how and when/where you have observed the implementation of each standard within your school's band program.

11. Students identify and describe the use of musical elements in a variety of music. (Grade 6)

$$
\text { Strongly disagree Disagree Neutral Agree Strongly agree Unsure }
$$

If possible, please provide an example of how and when/where this was observed. 
12. Students analyze the use of musical elements in a variety of music. (Grade 7)

Strongly disagree Disagree Neutral Agree Strongly agree Unsure

If possible, please provide an example of how and when/where this was observed.

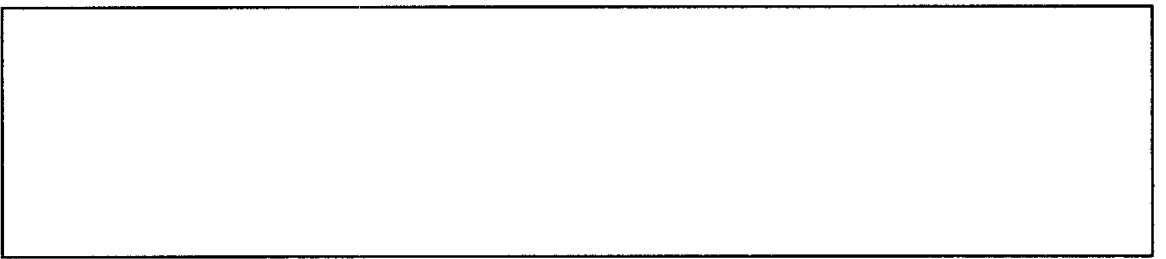

13. Students compare and evaluate the use of musical elements in a variety of music. (Grade 8)

Strongly disagree Disagree Neutral Agree Strongly agree Unsure

If possible, please provide an example of how and when/where this was observed.

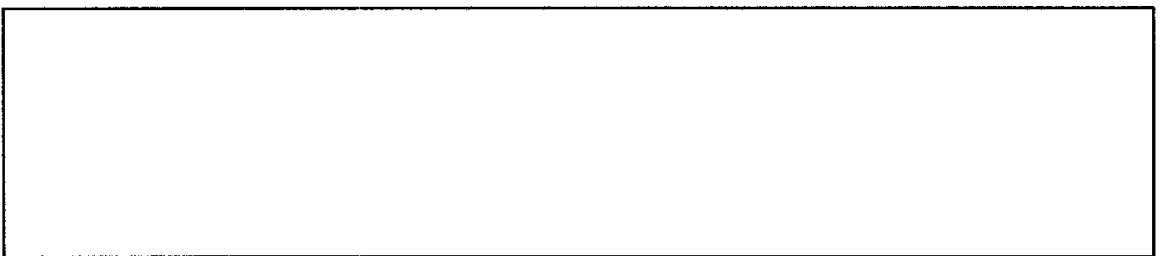

14. Students analyze or explain how diverse cultures and time periods are reflected in music.

Strongly disagree Disagree Neutral Agree Strongly agree Unsure

If possible, please provide an example of how and when/where this was observed.

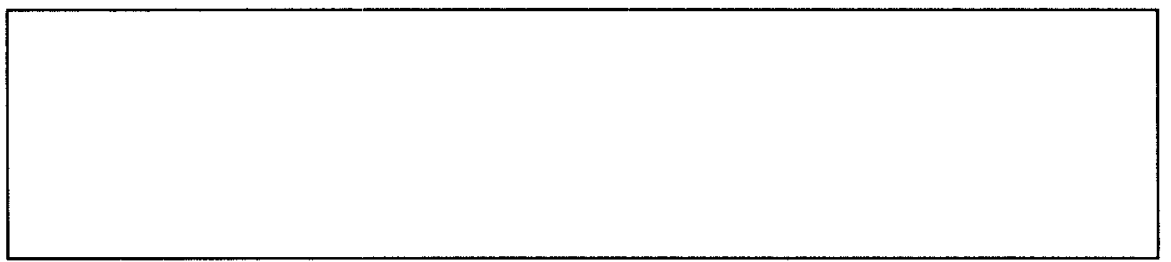

15. Students identify or explain how music fulfills a variety of purposes.

Strongly disagree Disagree Neutral Agree Strongly agree Unsure

If possible, please provide an example of how and when/where this was observed. 
16. Students create and notate, in similar style, answers to musical phrase.

Strongly disagree Disagree Neutral Agree Strongly agree Unsure

If possible, please provide an example of how and when/where this was observed.

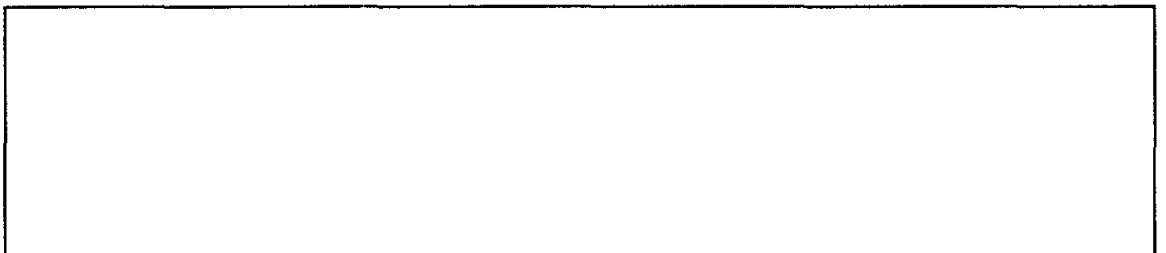

17. Students improvise variations on a given melody.

Strongly disagree Disagree Neutral Agree Strongly agree Unsure

If possible, please provide an example of how and when/where this was observed.

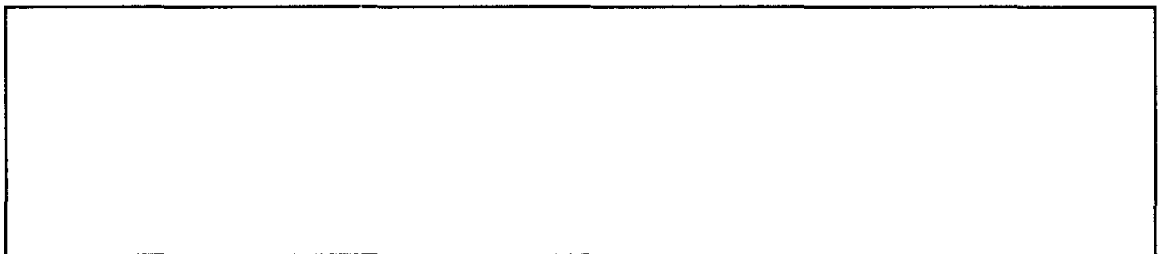

18. Students compose and notate short pieces of music demonstrating unity/variety, tension/release, and balance.

Strongly disagree Disagree Neutral Agree Strongly agree Unsure

If possible, please provide an example of how and when/where this was observed. 
19. Students use a variety of sound sources to create and perform music.

Strongly disagree Disagree Neutral Agree Strongly agree Unsure

If possible, please provide an example of how and when/where this was observed.

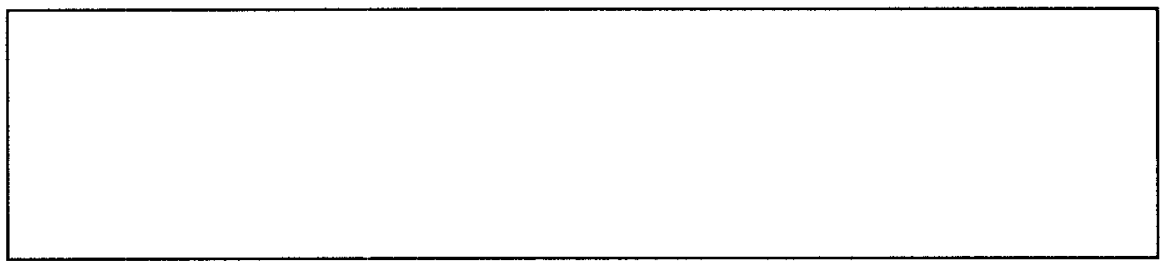

20. Students sing or play alone and sustain their own part in an ensemble, a given piece of music with increasingly complex melodies and rhythmic patterns in treble and bass clef, with practice.

Strongly disagree Disagree Neutral Agree Strongly agree Unsure

If possible, please provide an example of how and when/where this was observed.

Almost done! Just one more question. You are invited to participate in possible follow-up contacts beyond the basic questions you have answered online. If you are interested in being contacted for continued study purposes or would just like to receive the results of the completed study, please answer "yes" below. If you would not like to be contacted further in regards to this study and don't want to receive the results of this study simply select "no." Thank you for your time.

Are you interested in or willing to participate in follow-up questions regarding this study or in receiving the results of the study once completed?

YES

NO 


\section{HIGH SCHOOL (GRADES 9-12) SURVEY}

This study is seeking to survey administrator perceptions of KY Core Content for Assessment (CCA 4.1) in Music as implemented in band rehearsals or concerts by the band director.

To the best of your knowledge, please indicate your overall agreement with the following statements, as outlined in CCA 4.1.

If possible, please provide an example of how and when/where you have observed the implementation of each standard within your school's band program.

21. Students analyze or evaluate the use of musical elements in musical compositions.

Strongly disagree Disagree Neutral Agree Strongly agree Unsure

If possible, please provide an example of how and when/where this was observed.

22. Students analyze or evaluate how factors such as time, place, and ideas are reflected in music.

Strongly disagree Disagree Neutral Agree Strongly agree Unsure

If possible, please provide an example of how and when/where this was observed.

23. Students analyze or explain how diverse cultures and time periods are reflected in music.

$$
\text { Strongly disagree Disagree Neutral Agree Strongly agree Unsure }
$$

If possible, please provide an example of how and when/where this was observed. 
24. Students explain how music fulfills a variety of purposes.

Strongly disagree Disagree Neutral Agree Strongly agree Unsure

If possible, please provide an example of how and when/where this was observed.

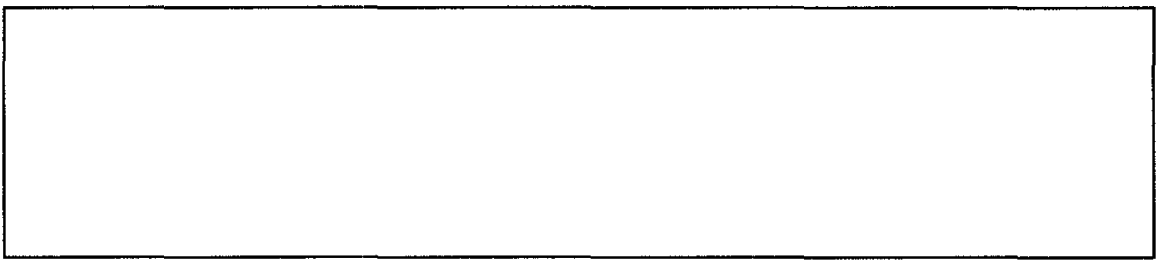

25. Students create and notate music.

Strongly disagree Disagree Neutral Agree Strongly agree Unsure

If possible, please provide an example of how and when/where this was observed.

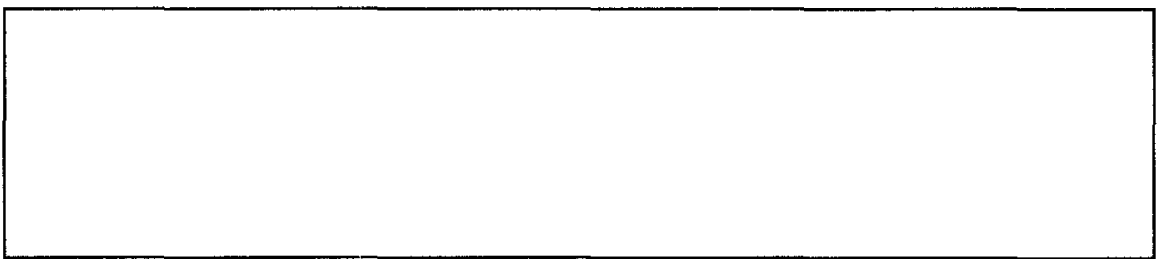

26. Students improvise rhythmic and/or melodic embellishments and variations on given melodies.

Strongly disagree Disagree Neutral Agree Strongly agree Unsure

If possible, please provide an example of how and when/where this was observed. 
27. Students sing or perform on instruments, alone and with others, by reading basic notation.

Strongly disagree Disagree Neutral Agree Strongly agree Unsure

If possible, please provide an example of how and when/where this was observed.

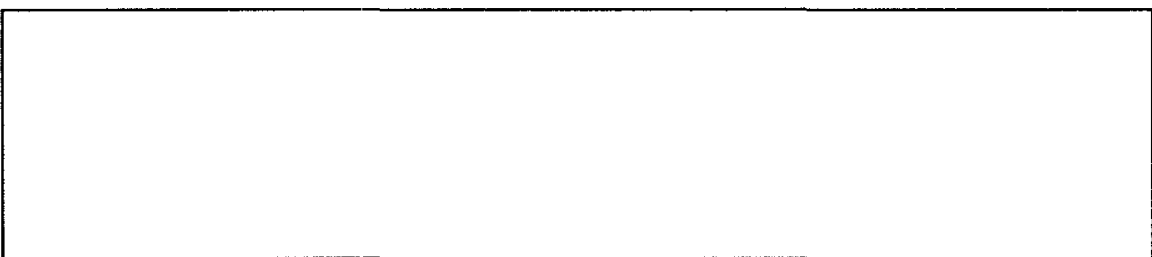

28. Students identify skills and training for a variety of careers related to music.

Strongly disagree Disagree Neutral Agree Strongly agree Unsure

If possible, please provide an example of how and when/where this was observed.

29. Students compare one art form (e.g. music) to another from the same stylistic period in another arts discipline (e.g. visual arts). For example, Impressionism: Monet to Debussy.

Strongly disagree Disagree Neutral Agree Strongly agree Unsure

If possible, please provide an example of how and when/where this was observed. 
30. Students analyze and/or explain how ideas and emotions expressed in one art form (e.g. music) are similar or different to ideas and emotions expressed in another art form (e.g. theatre).

Strongly disagree Disagree Neutral Agree Strongly agree Unsure

If possible, please provide an example of how and when/where this was observed.

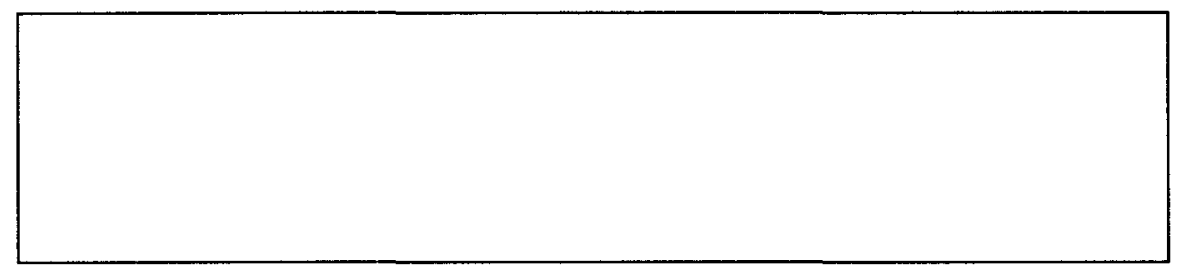

Almost done! Just one more question. You are invited to participate in possible follow-up contacts beyond the basic questions you have answered online. If you are interested in being contacted for continued study purposes or would just like to receive the results of the completed study, please answer "yes" below. If you would not like to be contacted further in regards to this study and don't want to receive the results of this study simply select "no." Thank you for your time.

Are you interested in or willing to participate in follow-up questions regarding this study or in receiving the results of the study once completed?

YES

NO 


\section{FOLLOW-UP CONTACT AND STUDY RESULTS}

Thank you for agreeing to a potential follow-up contact regarding this study. You may or may not be selected to participate in an interview or follow-up questions.

If you are interested in receiving the results of the study once completed, please indicate that below and provide your contact information.

Please provide your contact information below. Thank you.

31. Are you interested or willing to participate in a follow-up regarding this study?

YES

NO

Are you interested in receiving the results of this study once completed?

YES

NO

Please provide your contact information below. [Interview or follow-up questions]

Name:

School:

Email:

Phone:

Please provide your name and email address below. [Study results]

Name:

Email:

\section{THANK YOU!}

Thank you for your time. Your responses are appreciated. 


\title{
APPENDIX E
}

\author{
Survey (Band Director)
}

\section{CONSENT}

\section{Administrator and Band Director Perceptions of the Implementation of KY Core Content for Assessment in Music (Band Director)}

You have been invited to participate in a research study being conducted by David Buchholz, student at the University of Louisville, and Dr. Robert Amchin, Faculty Advisor. You are one of many other public secondary school administrators and band directors from the Louisville Metropolitan region and northwest-central Kentucky that have been invited to participate.

The purpose of this study is to understand administrator and band director perceptions of their school band program's implementation of the state of Kentucky's Core Content for Assessment 4.1 in music.

The following survey will ask you for demographic information about your school and then ask you to rate your level of agreement with ten (10) statements relating to CCA 4.1 for music and complete an equal number of short answer open response-type questions. The entire survey should take no more than 5-10 minutes to complete.

There are no foreseeable risks in participation, although there may be unforeseen risks.

The possible benefits of this study include a greater understanding among music educators of how their classroom instruction with regards to CCA 4.1 is perceived by band directors and their administrators. This information and other information collected may not benefit you directly, but it may be helpful to others.

You will not be compensated for your time, inconvenience, or expenses for your participation in this study.

Total privacy cannot be guaranteed. Your privacy will be protected by the extent permitted by law. If the results from this study are published, your name will not be made public. While unlikely, the following may look at the study records:

The University of Louisville institutional Review Board, Human Subjects Protection Program Office, and Privacy Office, Office for Human Research Protections (OHRP), Office of Civil Rights.

\section{All data collected in this study will be kept in a password protected computer.}

Taking part in this study is voluntary. You may choose to not take part at all. If you decide to be in this study you may stop taking part at any time. If you decide not to be in this study or if you stop taking part at any time, you will not lose any benefits for which you may qualify. 
You will be told about any changes that may affect your decision to continue in the study.

If you have any concerns or complaints about the study or study staff, you have three options.

You may contact David Buchholz (216) 401-7554 or Dr. Robert Amchin, Faculty Advisor (502) 852-0536

If you have any questions about your rights as a study subject, questions, concerns or complaints, you may call the Human Subjects Protection Program Office (HSPPO) (502) 852-

5188. You may discuss any questions about your rights as a subject, in secret, with a member of the Institutional Review Board (IRB) or the HSPPO staff. The IRB is an independent committee composed of members of the University community, staff of the institutions, as well as lay members of the community not concerned with these institutions.

The IRB has reviewed this study.

If you want to speak to a person outside of the University, you may call 1-877-852-1167. You will be given a chance to talk about any questions, concerns or complaints in secret. This is a 24hour hot line answered by people who do not work at the University of Louisville.

By clicking "Agree" below you are agreeing to take part in the study. By agreeing you are not giving up any legal rights. You may print a copy of this document to keep for your records by clicking here.

Do you agree to participate in the study, "Administrator and Band Director Perceptions of the Implementation of KY Core Content for Assessment in Music," as administered by David Buchholz, student in the University of Louisville School of Music?

YES

NO

\section{SCHOOL DEMOGRAPHICS}

Please answer the following demographic questions about your PRIMARY/HOME school and its band program ONLY.

For example, if you are a high school band director and also teach elementary band at another school, please only respond to the following questions with regard to your high school program.

1. Do you teach band at the secondary school level (grades 6-12)?

YES

NO 
2. Does your school REQUIRE any form of music instruction, such as band, choir, orchestra, and arts and humanities classes?

YES

NO

3. Who dictates the requirements for music instruction?

School Board

Site Based Decision Making council

school administration

music teacher

combination of any of the above

other

4. What grade levels do you teach at your primary school?

6-8

9-12

P-12

other

If you selected "other" for Question 4, please specify the grade levels you teach?

5. How would you describe you school's location?

urban

suburban

rural 
6. Approximately what percentage of students at your school receive free or reduced price lunches?

less than $10 \%$

$11-25 \%$

$26-50 \%$

$51-75 \%$

more than $75 \%$

7. How many students attend your school (approximately)?

8. How many students are in your band program (approximately)?

9. What music courses do you teach(select all that apply)?

general music

general music within an Arts \& humanities course

band

orchestra

choir/chorus

percussion ensemble

jazz band

piano/keyboard

guitar

music theory or history

other

If you selected "other" for Question 9, please specify what other courses you teach. 
10. Please specify the number of music specialists working at your school (full-time equivalent).

How many teach band (FTE)?

\section{PLEASE SELECT A GRADE LEVEL FOR THE SURVEY}

If you teach grades P-12, please select the option below that most closely aligns with the grade levels you teach at your primary school.

$6-8$

$9-12$

\section{PLEASE SELECT A GRADE LEVEL FOR THE SURVEY}

If you answered "other" to Question 4, please select the option below that most closely aligns with the grade levels you teach at your primary school.

$6-8$

$9-12$

\section{MIDDLE SCHOOL (GRADES 6-8) SURVEY}

This study is seeking to survey your perceptions and administrators' perceptions of KY Core Content for Assessment (CCA 4.1) in Music as implemented by you in band rehearsals or concerts.

Please indicate your overall agreement with the following statements, as outlined in CCA 4.1.

If possible, please provide an example of how and when/where you implement each of the standards within your school's band program.

11. Students identify and describe the use of musical elements in a variety of music. (Grade 6)

Strongly disagree Disagree Neutral Agree Strongly agree Unsure

If possible, please provide an example of how and when/where you implement this standard. 
12. Students analyze the use of musical elements in a variety of music. (Grade 7)

$$
\text { Strongly disagree Disagree Neutral Agree Strongly agree Unsure }
$$

If possible, please provide an example of how and when/where you implement this standard.

13. Students compare and evaluate the use of musical elements in a variety of music. (Grade 8 )

$$
\text { Strongly disagree Disagree Neutral Agree Strongly agree Unsure }
$$

If possible, please provide an example of how and when/where you implement this standard.

14. Students analyze or explain how diverse cultures and time periods are reflected in music.

$$
\text { Strongly disagree Disagree Neutral Agree Strongly agree Unsure }
$$

If possible, please provide an example of how and when/where you implement this standard.

15. Students identify or explain how music fulfills a variety of purposes.

$$
\text { Strongly disagree Disagree Neutral Agree Strongly agree Unsure }
$$

If possible, please provide an example of how and when/where you implement this standard. 
16. Students create and notate, in similar style, answers to musical phrase.

Strongly disagree Disagree Neutral Agree Strongly agree Unsure

If possible, please provide an example of how and when/where you implement this standard.

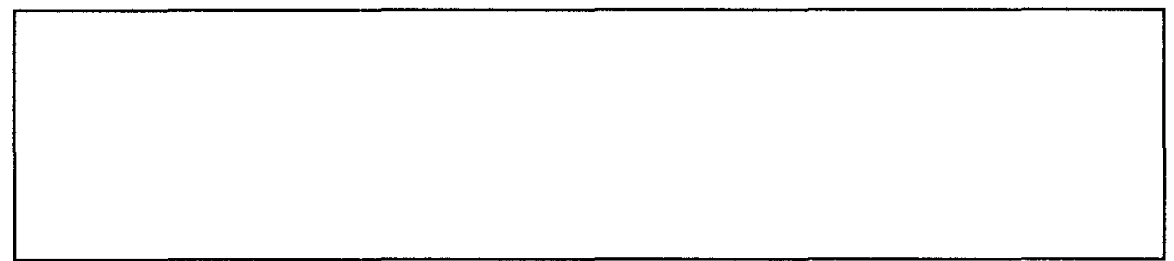

17. Students improvise variations on a given melody.

Strongly disagree Disagree Neutral Agree Strongly agree Unsure

If possible, please provide an example of how and when/where you implement this standard.

18. Students compose and notate short pieces of music demonstrating unity/variety, tension/release, and balance.

Strongly disagree Disagree Neutral Agree Strongly agree Unsure

If possible, please provide an example of how and when/where you implement this standard. 
19. Students use a variety of sound sources to create and perform music.

$$
\text { Strongly disagree Disagree Neutral Agree Strongly agree Unsure }
$$

If possible, please provide an example of how and when/where you implement this standard.

20. Students sing or play alone and sustain their own part in an ensemble, a given piece of music with increasingly complex melodies and rhythmic patterns in treble and bass clef, with practice.

$$
\text { Strongly disagree Disagree Neutral Agree Strongly agree Unsure }
$$

If possible, please provide an example of how and when/where you implement this standard.

Almost done! Just one more question. You are invited to participate in possible follow-up contacts beyond the basic questions you have answered online. If you are interested in being contacted for continued study purposes or would just like to receive the results of the completed study, please answer "yes" below. If you would not like to be contacted further in regards to this study and don't want to receive the results of this study simply select "no." Thank you for your time.

Are you interested in or willing to participate in follow-up questions regarding this study or in receiving the results of the study once completed?

YES

NO 


\section{HIGH SCHOOL (GRADES 9-12) SURVEY}

This study is seeking to your perceptions and administrators' of KY Core Content for Assessment (CCA 4.1) in Music as implemented by you in band rehearsals or concerts.

Please indicate your overall agreement with the following statements, as outlined in CCA 4.1.

If possible, please provide an example of how and when/where you implement each of the standards within your school's band program.

21. Students analyze or evaluate the use of musical elements in musical compositions.

$$
\text { Strongly disagree Disagree Neutral Agree Strongly agree Unsure }
$$

If possible, please provide an example of how and when/where you implement this standard.

22. Students analyze or evaluate how factors such as time, place, and ideas are reflected in music.

$$
\text { Strongly disagree Disagree Neutral Agree Strongly agree Unsure }
$$

If possible, please provide an example of how and when/where you implement this standard.

23. Students analyze or explain how diverse cultures and time periods are reflected in music.

$$
\text { Strongly disagree Disagree Neutral Agree Strongly agree Unsure }
$$

If possible, please provide an example of how and when/where you implement this standard. 
24. Students explain how music fulfills a variety of purposes.

Strongly disagree Disagree Neutral Agree Strongly agree Unsure

If possible, please provide an example of how and when/where you implement this standard.

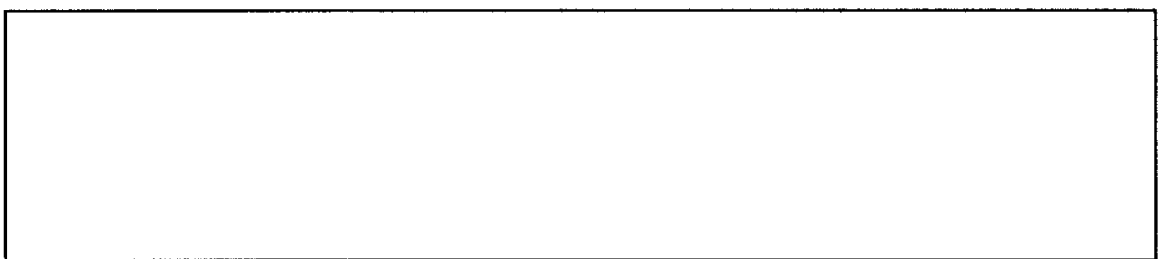

25. Students create and notate music.

Strongly disagree Disagree Neutral Agree Strongly agree Unsure

If possible, please provide an example of how and when/where you implement this standard.

26. Students improvise rhythmic and/or melodic embellishments and variations on given melodies.

Strongly disagree Disagree Neutral Agree Strongly agree Unsure

If possible, please provide an example of how and when/where you implement this standard.

27. Students sing or perform on instruments, alone and with others, by reading basic notation.

Strongly disagree Disagree Neutral Agree Strongly agree Unsure

If possible, please provide an example of how and when/where you implement this standard. 
28. Students identify skills and training for a variety of careers related to music.

\section{Strongly disagree Disagree Neutral Agree Strongly agree Unsure}

If possible, please provide an example of how and when/where you implement this standard.

29. Students compare one art form (e.g. music) to another from the same stylistic period in another arts discipline (e.g. visual arts). For example, Impressionism: Monet to Debussy.

Strongly disagree Disagree Neutral Agree Strongly agree Unsure

If possible, please provide an example of how and when/where you implement this standard.

30. Students analyze and/or explain how ideas and emotions expressed in one art form (e.g. music) are similar or different to ideas and emotions expressed in another art form (e.g. theatre).

Strongly disagree Disagree Neutral Agree Strongly agree Unsure

If possible, please provide an example of how and when/where you implement this standard. 
Almost done! Just one more question. You are invited to participate in possible follow-up contacts beyond the basic questions you have answered online. If you are interested in being contacted for continued study purposes or would just like to receive the results of the completed study, please answer "yes" below. If you would not like to be contacted further in regards to this study and don't want to receive the results of this study simply select "no." Thank you for your time.

Are you interested in or willing to participate in follow-up questions regarding this study or in receiving the results of the study once completed?

YES

NO

\section{FOLLOW-UP CONTACT AND STUDY RESULTS}

Thank you for agreeing to a potential follow-up contact regarding this study. You may or may not be selected to participate in an interview or follow-up questions.

If you are interested in receiving the results of the study once completed, please indicate that below and provide your contact information.

Please provide your contact information below. Thank you.

31. Are you interested or willing to participate in a follow-up regarding this study?

YES

NO

Are you interested in receiving the results of this study once completed?

YES

NO

Please provide your contact information below. [Interview or follow-up questions]

Name:

School:

Email:

Phone:

Please provide your name and email address below. [Study results]

Name:

Email: 


\section{THANK YOU!}

Thank you for your time. Your responses are appreciated. 


\section{CURRICULUM VITAE}

Name:

Birthplace:

Birth year:

Higher Education:

Experience:
David A. Buchholz

Cleveland, Ohio

December 10, 1985

University of Louisville

Louisville, Kentucky

Major: Music Education

Degree: MME (2012)

University of Louisville

Louisville, Kentucky

Major: Music Education

Degree: BME (2008)

Letcher County Public Schools

Whitesburg, Kentucky

2008-2010

Band (5-12)

Oldham County High School

Buckner, Kentucky

Spring 2008

Student Teacher, Band (6-12)

Trunnell Elementary School

Louisville, Kentucky

Spring 2008

Student Teacher, General Music (K-5) 